\title{
Impact of Oyster Farming on Diagenetic Processes and the Phosphorus Cycle in Two Estuaries (Brittany, France)
}

\author{
Françoise Andrieux-Loyer ${ }^{1, *}$, Afi Azandegbé ${ }^{2}$, Florian Caradec ${ }^{3}$, Xavier Philippon ${ }^{1}$, Roger Kérouel ${ }^{1}$, \\ Agnès Youenou ${ }^{1}$, Jean-Louis Nicolas ${ }^{2}$
}

\author{
${ }^{1}$ DYNECO PELAGOS, Ifremer, ZI Pointe du Diable, 29280, Plouzané, France \\ 2 PFOM-PI, Ifremer, 29280, Plouzané, France \\ ${ }^{3}$ RDT-EIM, Ifremer, 29280, Plouzané, France \\ *: Corresponding author : Françoise Andrieux-Loyer, email address : Francoise.Andrieux@lfremer.fr
}

\begin{abstract}
:
This study aims to compare the impact of oyster cultures on diagenetic processes and the phosphorus cycle in the sediments of the Aber Benoît and the Rivière d'Auray, estuary of Brittany, France. Our results showed clear evidence of the seasonal impact of oyster cultures on sediment characteristics (grain size and organic matter parameters) and the phosphorus cycle, especially in the Aber Benoît. At this site, seasonal variations in sulfide and $\mathrm{Fe}$ concentrations in pore waters, as well as $\mathrm{Fe}-\mathrm{P}$ concentrations in the solid phase, highlighted a shift from a system governed by iron reduction (Reference) to a system governed by sulfate reduction (beneath oyster). This could be partly explained by the increase in labile organic matter (i.e., biodeposits) beneath oysters, whose mineralization by sulfate led to high sulfide concentrations in pore waters (up to $4,475 \mu \mathrm{mol} \mathrm{I}{ }^{-1}$ ). In turn, sulfide caused an enhanced release of phosphate in the summer, as adsorption sites for phosphate decreased through the formation of iron-sulfide compounds (FeS and $\mathrm{FeS}_{2}$ ). In the Aber Benoît, dissolved $\mathrm{Fe} / \mathrm{PO}_{4}$ ratios could be used as an indicator of phosphate release into oxic water. Low $\mathrm{Fe} / \mathrm{PO}_{4}$ ratios in the summer indicated higher effluxes of phosphate toward the water column (up to $47 \mu \mathrm{mol} \mathrm{m} \mathrm{m}^{-2} \mathrm{~h}^{-1}$ ). At other periods, $\mathrm{Fe} / \mathrm{PO}_{4}$ ratios higher than $2 \mathrm{~mol} / \mathrm{mol}$ indicated very low phosphate fluxes. In contrast, in the Rivière d'Auray, the occurrence of macroalgae, stranding regularly all over the site, clearly masked the impact of oyster cultures on sediment properties and the phosphorus cycle and made the use of $\mathrm{Fe} / \mathrm{PO}_{4}$ ratios more difficult in terms of indicators of phosphate release.
\end{abstract}

Keywords: Sediment ; Phosphorus ; Sulfide ; Dissolved Fe/P ratios ; Labile organic matter ; Oyster cultures 


\section{Introduction}

Marine farming in France is currently dominated to a great extent by oyster farming. French oyster production, mainly the species Crassostrea gigas, represents 130,000 tonnes per year with a turnover close to 25 million euros per year, making France the leading European producer. However, summer mortalities of $\mathrm{C}$. gigas have been observed for several years along the French coast. An initial understanding of the complex interactions between oysters, environment, and pathogens was obtained during an interdisciplinary network, the MOREST project (2001-2005) on summer mortality events of C. gigas oysters in France (Samain and McCombie 2007). This project highlighted the involvement of multiple factors, including the genetic and physiological status of the oysters; the occurrence of pathogens and environmental factors such as temperature, high trophic conditions, which control reproduction intensity and susceptibility to bacterial infection; and sediment proximity (Samain and McCombie 2007). As an example of this last factor, in the Marennes-Oléron 
Bay, the daily mortality rates of "on-bottom" oysters, reared directly on intertidal sediments, were significantly higher than those of "off-bottom" oysters reared on trestles (Soletchnik et al., 2005 ; Gagnaire et al., 2006). This potential involvement of sediment in the occurrence of mortalities could be an indirect consequence of the impact of oyster farming activities on the sediment itself. The benthic effects of oyster farming, where no excess food is supplied seem to be much less serious than those of caged fish farming (Matijevic et al., 2008). However, several studies have demonstrated how bottom sediments below the oyster racks were highly polluted by organic matter due to the biodeposition of faeces and pseudofaeces, and silt sedimentation (Nugues et al., 1996 ; Mallet et al. 2006). Under these conditions high mineralization rates can occur, changing biogeochemical cycling to reactions that promote the release of large quantities of inorganic nutrients into the water column (Berelson et al., 1998). In fact, when high mineralization rates occur, oxygen becomes depleted and sulphate reduction is stimulated leading to increased sulfide and ammonia production, which are known to be toxic to macroorganisms. In addition, the occurrence of anoxic conditions may contribute to an increase in phosphate liberation through the dissolution of Fe(III)-bound-P (Andrieux-Loyer and Aminot, 2001 ; Andrieux-Loyer et al., 2008 ; Anschutz et al., 1998 ; Krom and Berner, 1980, 1981 ; Sundby et al., 1992). This additional released P may significantly increase the biologically available pool of $\mathrm{P}$ in the water, thus modifying the trophic resource.

The effect of shellfish farming has especially been studied concerning nitrogen dynamics (Pietros and Rice, 2003 ; Mazouni, 2004 ; Nizzoli et al., 2006). However, relatively little is known of the impact of oyster cultures on mineralization processes and nutrient dynamics regarding the phosphorus cycle and including both the speciation of particulate phosphorus forms and dissolved nutrient data (Anschutz et al., 2007). Most studies on the impact of oyster cultures on nutrient cycles have mainly focused on nutrient fluxes (Gaertner-Mazouni et al., 2012 ; Hyun et al., 2013). focusing on the phosphorus cycle and how these effects differ according to seasons and sites. This study also 61 provides important data for drawing up oyster aquaculture models, which do not yet adequately describe the effects of shellfish farms on benthic nutrient fluxes (Giles et al., 2006). 


\section{1. Site description}

Sampling was conducted in two French estuaries where oyster farming is highly developed (figure $1 \mathrm{~A}$ and B) : (1) the downstream part of the Aber Benoît $\left(4^{\circ} 36^{\prime} \mathrm{W}\right.$ and $\left.47^{\circ} 36^{\prime} \mathrm{N}\right)$ and (2) an oyster culture site (Fort Espagnol) near the mouth of the Rivière d'Auray $\left(2^{\circ} 58^{\prime} \mathrm{W}\right.$ and $\left.47^{\circ} 36^{\prime} \mathrm{N}\right)$.

The Aber Benoît (figure $1 \mathrm{~B}_{1}$, table 1) is an estuary $31 \mathrm{~km}$ in length, with a catchment area of $140 \mathrm{~km}^{2}$, situated in the Northwest of Finistère (Brittany). The average water flow in spring is $0.418 \mathrm{~m}^{3} \mathrm{~s}^{-1}$ but this site is subjected to strong seawater currents (up to $1.3 \mathrm{~m} \mathrm{~s}^{-1}$ ) due to the high tidal amplitude, and salinity ranges from 24 to 34 (PSS78). Depth at zero tide is $14 \mathrm{~m}$. Human activities, which mainly center on animal husbandry, lead to moderate discharges of organic matter, nitrate-rich fertilizers and sometimes pesticides into Aber Benoît. The total oyster area (250 ha) is located within Aber Benoit (38 ha) and Aber Wrac'h and between them. Before 2008 , no summer mortality occurred and the temperatures never reached $19{ }^{\circ} \mathrm{C}$.

The estuarine area of Auray (figure $1 \mathrm{~B}_{2}$, table 1 ) is $56.4 \mathrm{~km}$ in length and represents the western part of the Gulf of Morbihan in South Brittany. It is influenced by human activities, mainly agriculture, in a catchment area of $800 \mathrm{~km}^{2}$ around two principal rivers, the Loch and the Sal. These rivers flow into Rivière d'Auray with an average flow of $2.99 \mathrm{~m}^{3} \mathrm{~s}^{-1}$ for the Loch and about half this for the Sal. The tidal flux causes a renewal of $50 \%$ of the Gulf's water every 10 days (20 tides) and produces a current up to $0.4 \mathrm{~m} \mathrm{~s}^{-1}$. In the downstream part of Rivière d'Auray, which is used for oyster farming (1635 ha), salinity varies from 27 to 35 (PSS78). Depth at zero tide is $20 \mathrm{~m}$. Oyster mortality has occurred almost every year since the phenomenon began, notably because the temperatures exceed $19^{\circ} \mathrm{C}$ in summer.

Both sites are well-suited for breeding oysters due to the presence of phytoplankton blooms.

The sediment of Aber Benoît is sandy mud with a deep grey colour, while the Rivière d'Auray sediment is black sandymud.

In each site, experiments were performed, over a seasonal cycle, at a station under the influence of oyster cultures (Oyster) compared to processes at a station outside their direct influence (Reference, $30 \mathrm{~m}$ away from Oysters). However, as all Rivière d'Auray was subjected to green macroalgal growths, a reference site without these macroalgae could not be found. 

spring tide. Pacific oysters Crassostrea Gigas were reared in bags placed on $50 \mathrm{~cm}$ high racks on each sample site.

\section{2. Sampling}

In each site, sediment samples were collected on a monthly basis from July to September 2007 and in

March, May and June 2008. Sediment and its overlying water were collected by a hand corer using PVC cores (id $=9 \mathrm{~cm} ; \mathrm{h}=30 \mathrm{~cm}$ ), as described in Mudroch and Azcue (1995). Any disturbance of the sediment-water interface was carefully avoided. Triplicate cores were taken at each station. This study was carried out during similar hydrodynamic conditions (moderate spring tide, ebb tide). Overlying physical-chemical water properties are illustrated in figure 2 .

102

\section{3. Overlying and pore water treatments}

All overlying and pore water treatments were performed at the sampling site. An aliquot of overlying water was collected immediately after core recovery for further nutrient analyses. Temperature and Salinity

106 (expressed on the PSS78 scale) in overlying waters were measured with a WTW portable meter (LF 320). High resolution vertical profiling of dissolved $\mathrm{O}_{2}$ was then carried out both in overlying and pore waters using a miniaturized Clark-type oxygen sensor (Unisense OX500) coupled with a picoammeter (Unisense PA2000) and a micromanipulator (Unisense MM33). The in-situ temperature was maintained by using an insulating device.

$1118 \mathrm{~cm}(0.5 \mathrm{~cm}$ for the top $1 \mathrm{~cm}, 1 \mathrm{~cm}$ up to $3 \mathrm{~cm}, 2 \mathrm{~cm}$ up to $5 \mathrm{~cm}, 3 \mathrm{~cm}$ below) within $30 \mathrm{~min}$. Two other cores

112 were sliced up to $2 \mathrm{~cm}$ for diffusive fluxes statistical treatments. For every level, a sub-sample was centrifuged in 113 a Whatman VectaSpin 20TM centrifuge tube filter $(0.45 \mu \mathrm{m})$ under inert atmosphere $\left(\mathrm{N}_{2}\right)$ at $3075 \mathrm{~g}$ and $4{ }^{\circ} \mathrm{C}$ for $11420 \mathrm{~min}$ in order to collect pore waters. 


\section{4. Sediment treatments}

An aliquot of the wet sediment of known volume and weight was dried at $60^{\circ} \mathrm{C}(5$ days) and the weight loss was used to calculate porosity (Berner, 1980). Another sample was maintained at $4{ }^{\circ} \mathrm{C}$ for less than 15 days for sediment grain size. An aliquot of the sediment remaining after collection of pore water was frozen at $-25^{\circ} \mathrm{C}$ for subsequent Chlorophyll a (Chl a) and Phaeopigment analysis. Another aliquot was also frozen at $-25{ }^{\circ} \mathrm{C}$, then freeze-dried, for the subsequent organic Carbon (Orga-C), total N, and phosphorus forms analysis.

\section{Sequential extraction of phosphorus pools and analysis}

The major reservoirs of sedimentary P -Adsorbed and iron-oxide bound P (Fe-P) and Authigenic Calcium bound P (Auth-Ca-P)- were determined using the widespread sequential method of Ruttenberg (1992), as modified by Andrieux-Loyer et al., 2008. The main features are presented in table 2. In this study, we omitted citrate in the first step as it was shown to render a part of the calcium-bound phosphate soluble (Psenner, 1988). In addition, the $\mathrm{MgCl}_{2}$ and $\mathrm{H}_{2} \mathrm{O}$ washes were omitted in step I. These were originally used to avoid the secondary sorption of $\mathrm{P}$ on the residual solid surfaces during the extractions. This process was shown to be insignificant in the dithionite extraction (Ruttenberg, 1992 ; Slomp, 1996 a).

Organic P (Orga-P) was determined nonsequentially as the difference between $1 \mathrm{M} \mathrm{HCl}$ extractable $\mathrm{P}$ before $(24 \mathrm{~h}$ : inorganic $\mathrm{P})$ and after the ignition of the sediment $\left(550^{\circ} \mathrm{C}, 4 \mathrm{~h}\right.$; Total P ; Aspila et al., 1976). The sedimentary inorganic carbon was removed with phosphoric acid (Cauwet, 1975) before Orga-C analysis.

\section{5. Analytical procedures}

The analysis of sediment grain size was performed using LS 200 Beckman Coulter laser granulometry. Organic $\mathrm{C}$ (Orga-C) and total $\mathrm{N}$ were measured using a vario EL-III $\mathrm{CN}$ elemental analyser. $\mathrm{Chl}$ a and Phaeopigments were determined according to Lorenzen (1967) as modified by Aminot and Kerouel (2004).

143 and dithionite extracts were additionally acidified with $\mathrm{H}_{2} \mathrm{SO}_{4}$ (Jensen and Thamdrup, 1993), then bubbled with

144 pure $\mathrm{O}_{2}\left(30 \mathrm{ml} \mathrm{min}^{-1}\right)$ for one minute to transform $\mathrm{S}$ in $\mathrm{SO}_{4}$, which may interfere in colorimetric methods and 
145 phosphate determination in the extracts. The method of standard additions was used to check for potential 146 interferences and to correct the results accordingly. according to Fonselius et al., 1999.

\section{6. Calculation of diffusive fluxes}

$155 \mathrm{Fd}=-\phi \times \mathrm{Ds} \times\left(\frac{\mathrm{dC}}{\mathrm{dz}}\right)(1)$, where $\mathrm{Fd}$ is the rate of efflux $\left(\mu \mathrm{mol} \mathrm{m} \mathrm{m}^{-2} \mathrm{~d}^{-1}\right), \Phi$ is the sediment porosity

156 (dimensionless) of the upper sediment sample, Ds is the bulk diffusion coefficient $\left(\mathrm{m}^{-2} \mathrm{~d}^{-1}\right)$ and $\mathrm{dC} / \mathrm{dz}$ is the

157 concentration gradient at sediment-water interface for phosphate and ammonium $\left(\mu \mathrm{mol} \mathrm{m} \mathrm{m}^{-4}\right)$. For $\mathrm{HPO}_{4}^{2-}$ and

$158 \mathrm{NH}_{4}{ }^{+}, \mathrm{dC} / \mathrm{dz}$ was calculated from linear regression on the concentration values at bottom water and just below 159 the interface (table 3). For $\mathrm{HS}^{-}$, the concentration gradient was calculated for the depth interval with the greatest 160 concentration gradient change (table 3), with corresponding porosity (Sahling et al., 2002). Consequently, these

161 sulfide fluxes represented the maximum of the ascendant sulfide fluxes in the sediment. Ds was corrected for

162 tortuosity, i.e., $D_{s}=\frac{D_{0}}{\theta^{2}}$, where $\theta$ is the tortuosity (dimensionless), $\mathrm{D}_{0}$ is the diffusion coefficient in water for

$163 \mathrm{HPO}_{4}{ }^{2-}, \mathrm{NH}_{4}^{+}$or $\mathrm{HS}^{-}\left(\mathrm{m}^{2} \mathrm{~d}^{-1}\right)$. The diffusion coefficient in water $\left(\mathrm{D}_{0}\right)$ was corrected for the in situ bottom water

164 temperatures ( $\mathrm{Li}$ and Gregory, 1974) and the value of $\theta$ was assumed to be equal to $\sqrt{1-2 \times \ln \varphi}$ (Boudreau, 165 1996). 


\section{II.8 Data processing}

168

169

170

171

172

173

174

175

176

177

178

179

180

181

182

183

184

185

186

187

188

189

190

191

192

Surfer $^{\circledR}$ software (version 8) was used to interpolate measured values and create contour maps for each measured solid and dissolved parameter. The gridding methods in Surfer uses weighted average interpolation algorithms. Kriging, used in this study, is the default gridding method because it generates the best overall interpretation of most data sets.

The normality of data sets was first assessed with the Shapiro \& Wilk test (www.anastats.fr). Speerman or Bravais-Pearson tests were used to evaluate relationships between variables (Xlstat). Mann and Whitney tests were performed to determine the significant differences of biogeochemical parameters between the Reference and Oyster stations at each study period (www.anastats.fr). For all tests, values were considered significant at $\mathrm{p}$ $<0.01$.

\section{Results}

\section{III.1. Solid fraction}

III.1.1. Sediment characteristics (granulometry, porosity, Carbon, Nitrogen and Chlorophyll a)

Sediment characteristics of surficial sediments (in the top $3 \mathrm{~cm}$ ) are presented in table 4 and in table 5 in Appendix. Sediments were all sandy muds both in the Aber Benoît and in the Rivière d'Auray (Characterization of Larsonneur, 1971). Nevertheless, surficial sediments in the Aber Benoît always presented lower proportions of lutites $(<62.5 \mu \mathrm{m})$ than those in the Rivière d'Auray, both at the Reference and under Oysters (table 4). In the Aber Benoit, proportions of lutites (and the lowest median size) were always significantly higher beneath Oysters compared to the Reference (Mann and Whitney; $\mathrm{n}=6 ; \mathrm{p}<0.01$ ), whereas no differences appeared in rivière d'Auray $(n=6 ; p<0.01)$. Coefficients of variations in the Aber Benoit $(8 \%$ under racks ; $22 \%$ outside racks) and in the Rivière d'Auray ( $7 \%$ under rack ; $8 \%$ at the Reference) indicated the relatively stable grainsize nature of surficial sediments at each station over time.

The surficial porosities were lower in the Aber Benoît than in the Rivière d'Auray (table 4). However, at both areas, differences between Reference and Oyster sites were not significant at each study period (MannWhitney tests $; \mathrm{n}=6 ; \mathrm{p}<0.01)$. 

or almost constant concentrations with depth, according to the season and the location. However, in the Aber

195 Benoît in May and June, under Oysters, a significant increase in concentrations occurred respectively at 2-3 cm depth and at 5-7 $\mathrm{cm}$ depth (Orga-C $>2100-2700 \mu \mathrm{mol} \mathrm{g} \mathrm{g}^{-1}$; Total $\left.\mathrm{N}:>400 \mu \mathrm{mol} \mathrm{g}{ }^{-1}\right)$. At the Reference, concentrations only increased in May in surficial sediments (Orga-C $>1200 \mu \mathrm{mol} \mathrm{g}^{-1}$; Total N $\left.>200 \mu \mathrm{mol} \mathrm{g}^{-1}\right)$. In the Rivière d'Auray, seasonal variations occurred both under Oysters and at the Reference and the highest surficial concentrations $\left(\sim 2700 \mu \mathrm{mol} \mathrm{g}^{-1}\right.$ in Orga-C ; $500 \mu \mathrm{mol} \mathrm{g}^{-1}$ in Total $\left.\mathrm{N}\right)$ were always observed in May and August. and Rivière d'Auray). At both sites, $\mathrm{C} / \mathrm{N}$ ratios increased from March $(6.1 \pm 0.5)$ to Summer $(9.0 \pm 0.6$ in the Aber Benoît and $9.4 \pm 0.2$ in the Rivière d'Auray).

Orga-C/Orga-P (C/P) ratios (figure 4) were more variable further down the core, generally increasing with depth. They also increased from March (about $230 \pm 20$ under Oysters in the Aber Benoit and $230 \pm 154$ under Oysters in the Rivière d'Auray) to June (393 \pm 111 in the Aber Benoit at the Reference) or to July (724 \pm 222 in the Rivière d'Auray under Oysters). There were no significant differences in $\mathrm{C} / \mathrm{N}$ and $\mathrm{C} / \mathrm{P}$ ratios between Reference and Oyster sites.

Chl a concentrations (figure 3), in the Aber Benoit, under Oysters, were characterized by two maxima (May, $50 \mu \mathrm{g} \mathrm{g}^{-1}$ in surficial layers ; June, $40 \mu \mathrm{g} \mathrm{g}^{-1}$ at $6 \mathrm{~cm}$ depth). At the Reference, concentrations rarely exceeded $10-20 \mu \mathrm{g} \mathrm{g}^{-1}$. In the Rivière d'Auray, both under Oysters and at the Reference, two maxima also occurred, respectively in May and August (up to $70 \mu \mathrm{g} \mathrm{g}^{-1}$ ) and in March and May (up to $80 \mu \mathrm{g} \mathrm{g}^{-1}$ ). up to $120 \mu \mathrm{g} \mathrm{g}^{-1}$ (Aber Benoît, under Oysters) and up to $211 \mu \mathrm{g} \mathrm{g}^{-1}$ (Rivière d'Auray, Reference).

\section{III.1.2. P forms}


P concentrations were characterized by two maxima, the first one in May $\left(24 \mu \mathrm{mol} \mathrm{g} \mathrm{g}^{-1}\right.$ at $\left.2.5 \mathrm{~cm} \mathrm{depth}\right)$, the 221 second in June in deeper layers $\left(24 \mu \mathrm{mol} \mathrm{g}^{-1}\right.$ at $6 \mathrm{~cm}$ depth). At the Reference, concentrations only significantly 222 increased in May $\left(20 \mu \mathrm{mol} \mathrm{g}^{-1}\right.$ at $1 \mathrm{~cm}$ depth). In the rivière d'Auray, two maxima occurred in surficial 223 sediments both under Oysters (about $24 \mu \mathrm{mol} \mathrm{g}^{-1}$ in May and August) and at Reference (20-26 $\mu \mathrm{mol} \mathrm{g}^{-1}$ in March and September). Apart from these maxima, concentrations ranged from 10 to $15 \mu \mathrm{mol} \mathrm{g} \mathrm{g}^{-1}$. Total $\mathrm{P}$ distributions were largely accounted for by Orga-P and Fe-P which globally showed the same patterns and to a lesser extent by Authigenic Ca-P.

In both areas, Fe-P mean concentrations were close to $2 \mu \mathrm{mol} \mathrm{g} \mathrm{g}^{-1}$. In the Aber Benoît, under Oyters, concentrations reached about $5 \mu \mathrm{mol} \mathrm{g}^{-1}$ in May and June (2-6 cm depth). At the Reference, there was no significant increase. In the Rivière d'Auray, under Oysters, Fe-P concentrations in surficial sediments, showed a first increase in May and a second at the end of August (up to $11 \mu \mathrm{mol} \mathrm{g}^{-1}$ ). At the Reference, the first maximum occurred in March $\left(8.8 \mu \mathrm{mol} \mathrm{g}^{-1}\right.$ at $0.5 \mathrm{~cm}$ depth) and the second in August $\left(5.7 \mu \mathrm{mol} \mathrm{g}^{-1}\right.$ at $\left.2.5 \mathrm{~cm} \mathrm{depth}\right)$. This phosphorus form represents 10 to $20 \%$ of the total phosphorus in the Aber Benoit and 10-30\% of Total P in the Rivière d'Auray. No significant variations in proportions could be observed whatever the investigated area and site.

In the Aber Benoit, under Oysters, Orga-P patterns were characterized by an increase in concentrations both in May (12 $\mu \mathrm{mol} \mathrm{g}^{-1}$ at $2.5 \mathrm{~cm}$ depth) and June $\left(9.4 \mu \mathrm{mol} \mathrm{g} \mathrm{g}^{-1}\right.$ at $6 \mathrm{~cm}$ depth). At the Reference, concentrations only increased in March and May in surficial sediments (up to $7.4 \mu \mathrm{mol} \mathrm{g}^{-1}$ ). In the Rivière d'Auray, under Oyters, two maxima (up to $11.5 \mu \mathrm{mol} \mathrm{g}^{-1}$ ) occurred in surficial sediments in May and August, whereas at the Reference, concentrations increased especially in May and at the end of September. Owing to the relatively wide concentration range $\left(0-12 \mu \mathrm{mol} \mathrm{g}^{-1}\right)$-according to the location and the season- the Orga-P proportions in relation to total $\mathrm{P}$ were relatively variable (15-30\% on average in the Aber Benoit ; $20-45 \%$ on average in the Rivière d'Auray). No significant trend could be highlighted between Reference and Oyster sites, either in the Aber Benoît or in the Rivière d'Auray.

By and large, almost constant Auth-Ca-P concentrations occurred in the Rivière d'Auray (2-3 $\left.\mu \mathrm{mol} \mathrm{g}^{-1}\right)$. In contrast, in the Aber Benoit, two concentration maxima (4- $\left.6 \mu \mathrm{mol} \mathrm{g}^{-1}\right)$ were observed both beneath Oysters and Reference, in May, June or July. Auth-Ca-P accounted for 10 to $18 \%$ and 12 to $23 \%$ of total P respectively in the Aber Benoît and in the Rivière d'Auray. The proportions of Auth-Ca-P did not display any effects of 248 oyster cultures. 


\section{III.2. Pore water profiles}

III.2.1. Redox sensitive species $\left(\mathrm{O}_{2}, \mathrm{NO}_{3}^{-}, \mathrm{Fe}^{2+}\right.$ and $\left.\mathrm{Mn}^{2+}, \mathrm{HS}\right)$

In the Aber Benoit, under Oysters, oxygen concentrations in the bottom waters (figure 6) varied from $235 \mu \mathrm{mol} \mathrm{l} \mathrm{l}^{-1}$ (July 3th) to about $300 \mu \mathrm{mol} \mathrm{l}^{-1}$ (June) over the study period. For the Reference, concentrations varied from $255 \mu \mathrm{mol} \mathrm{l}^{-1}$ (May) and $285 \mu \mathrm{mol} \mathrm{l}^{-1}$ (March) with an increase (up to $340 \mu \mathrm{mol} \mathrm{l}^{-1}$ ) at $0.8 \mathrm{~cm}$ above the sediment. In the Rivière d'Auray, concentrations in the bottom waters under Oysters ranged from $165 \mu \mathrm{mol} \mathrm{1}^{-}$ ${ }^{1}$ (August $1^{\text {st }}$ ) and $305 \mu \mathrm{mol} \mathrm{l}^{-1}$ (June). At the Reference, concentrations ranged from $200 \mu \mathrm{mol}^{-1}$ in August to $320 \mu \mathrm{mol} \mathrm{l}^{-1}$ in March. The concentration profiles of $\mathrm{O}_{2}$ always showed a sharp negative concentration gradient presenting the sediment as a sink for dissolved oxygen whatever the season or the location. $\mathrm{O}_{2}$ was always consumed within the first millimetres below the sediment-water interface. The penetration depths of dissolved oxygen profiles in the Aber Benoit ranged from $2 \mathrm{~mm}$ (August: Reference ; May: Oysters) to $3.8 \mathrm{~mm}$ (March: Oysters ; September: Reference). Nevertheless, a sporadic increase in $\mathrm{O}_{2}$ concentrations was observed in the sediment in June and July in the Aber Benoît at the Reference. In the Rivière d'Auray, the penetration depths varied from $2.6 \mathrm{~mm}$ (September: Oysters ; June: Reference) to $4.7 \mathrm{~mm}$ (September: Reference). 11) in relation to the bottom water, suggesting that the sediment is a sink for nitrate. By and large, $\mathrm{NO}_{3}^{-}$ vanished totally below $1 \mathrm{~cm}$ depth (Table 5 in Appendix).

No data were available for dissolved $\mathrm{Fe}$ and $\mathrm{Mn}$ in bottom waters. $\mathrm{Mn}^{2+}$ and $\mathrm{Fe}^{2+}$ pore water profiles 267 (figure 7) indicated the sediment dissolution of $\mathrm{Mn}$ and $\mathrm{Fe}$ oxides. In the Aber Benoît, under Oysters, $\mathrm{Fe}^{2+}$ 268 profiles highlighted an increase at depth where nitrate disappeared (up to $199 \mu \mathrm{mol}^{-1}$ ) in March and May and at 269 the end of September (up to $99 \mu \mathrm{mol}^{-1}$ ). Then, concentrations decreased below 3-4 $\mathrm{cm}$. At the other periods, concentrations were close to $10 \mu \mathrm{mol} \mathrm{l}^{-1}$ at all depths, both under Oysters and at the Reference. In the Rivière 271 d'Auray, two maxima occurred in surficial sediments, the first one in March (Reference, up to $320 \mu \mathrm{mol}^{-1}$ ) or 272 May (Oysters, up to $221 \mu \mathrm{mol} \mathrm{1}^{-1}$ ), the second in August (Oysters, up to $540 \mu \mathrm{mol}^{-1}$ ) or in September more in 273 depth (Reference, up to $232 \mu \mathrm{mol}{ }^{-1}$ ). $\mathrm{Mn}^{2+}$ profiles (figure 7) generally displayed the same patterns as $\mathrm{Fe}^{2+}$ but with concentrations rarely exceeding $15 \mu \mathrm{mol}^{-1}$. 

8). In the Aber Benoît, under Oysters, concentrations increased up to $4475 \mu \mathrm{mol} \mathrm{l}^{-1}$ at $7 \mathrm{~cm}$ depth in June and up to $2792 \mu \mathrm{mol} \mathrm{l}^{-1}$ at 4-7 $\mathrm{cm}$ depth in August (figure 8). At the Reference, concentrations were always lower than $70 \mu \mathrm{mol} \mathrm{l}^{-1}$ (figure 8). In the Rivière d'Auray, a different pattern occurred with lower concentrations $(<500$ $\mu \mathrm{mol}^{-1}$ ) under Oysters compared to the Reference (up to $2415 \mu \mathrm{mol}^{-1}$ in May at 4-5 cm depth). Sulfide was never detected in the water column at either areas.

\section{II.2.2. Phosphate and ammonium profiles}

In both areas, phosphate concentrations in the bottom waters rarely exceeded $1 \mu \mathrm{mol} \mathrm{l}^{-1}$. In the Aber

Benoît, pore water phosphate concentrations were significantly higher under oysters compared to the Reference, with concentrations exceeding $70 \mu \mathrm{mol} \mathrm{l}^{-1}$ from $2 \mathrm{~cm}$ depth in May and June and from 4 to $7 \mathrm{~cm}$ depth in September (figure 8). At the Reference, concentrations rarely exceeded $10 \mu \mathrm{mol} \mathrm{l^{-1 }}$. On the contrary, in the Rivière d'Auray, both Oyster and Reference sites exhibited pore water concentrations seasonnaly higher than 70 $\mu \mathrm{mol} 1^{-1}$ (figure 8). Surficial pore water concentrations were generally higher than in the Aber Benoit (20-30 $\mu$ mol $\mathrm{l}^{-1}$ against 10-15 $\mu \mathrm{mol}^{-1}$ ). Ammonium profiles displayed the same behaviour as phosphate profiles but with about 20-30 and 8-12 times higher concentration levels, respectively in the Aber Benoît and the Rivière d'Auray (figure 8).

\section{III.3. Calculated diffusive fluxes}

Phosphate benthic fluxes (figure 9) calculated from pore water gradients using Equation (1) (§ II.6) ranged from $1 \pm 0.1 \mu \mathrm{mol} \mathrm{m}{ }^{-2} \mathrm{~h}^{-1}$ in September to $45 \pm 11 \mu \mathrm{mol} \mathrm{m}^{-2} \mathrm{~h}^{-1}$ in June and from $1.8 \pm 0.2 \mu \mathrm{mol} \mathrm{m}^{-2} \mathrm{~h}^{-1}$ in March to $19 \pm 10 \mu \mathrm{mol} \mathrm{m}^{-2} \mathrm{~h}^{-1}$ in September, respectively in the Aber Benoit and in the Rivière d'Auray under Oysters. At the References, phosphate fluxes never exceeded $6 \mu \mathrm{mol} \mathrm{m} \mathrm{m}^{-2} \mathrm{~h}^{-1}$.

A similar pattern was observed for ammonium under Oysters (figure 9), where fluxes varied from 68 $300 \pm 6 \mu \mathrm{mol} \mathrm{m}^{-2} \mathrm{~h}^{-1}$ (March) to $1014 \pm 137 \mu \mathrm{mol} \mathrm{m}^{-2} \mathrm{~h}^{-1}$ (beginning of July) in the Aber Benoit and from $116 \pm 16$ $\mu \mathrm{mol} \mathrm{m} \mathrm{m}^{-2} \mathrm{~h}^{-1}$ (March) to $317 \pm 47 \mu \mathrm{mol} \mathrm{m} \mathrm{m}^{-2} \mathrm{~h}^{-1}$ (May) in the Rivière d'Auray. At the Reference, the highest ammonium fluxes appeared in May at both areas $\left(39 \pm 16 \mu \mathrm{mol} \mathrm{m}^{-2} \mathrm{~h}^{-1}\right.$ in the Aber Benoit; $206 \pm 47 \mu \mathrm{mol} \mathrm{m} \mathrm{h}^{-2}$ in the Rivière d'Auray). 
306 were generally higher under Oysters (up to $50 \mu \mathrm{mol} \mathrm{m}^{-2} \mathrm{~h}^{-1}$ ), except in May and September (148 and $96 \mu \mathrm{mol} \mathrm{m}$ $307{ }^{2} \mathrm{~h}^{-1}$ at the Reference).

308 
The present study aimed to compare the impact of oyster farming on sediment properties and the

311 phosphorus cycle in two contrasted estuaries. Our findings showed clear evidence of the seasonal impact of 312 oyster cultures on sediment characteristics, mineralization processes and the phosphorus cycle in the Aber 313 Benoît. In contrast, in the Rivière d'Auray, the occurence of macroalgae clearly masked this impact.

\section{V.1 Impact of oyster culture on grain size and organic matter parameters}

Aquaculture activities are known to lead to an increase in fine particles in sediments, as in oyster cultures, where $95 \%$ of particles of oyster feces and pseudofeces are less than $5 \mu \mathrm{m}$ (Sornin, 1984). These

318 biodepositions may increase sedimentation by a factor of 2-4, depending on the area (Nugues et al., 1996 ; 319 Forrest and Creese, 2006). Grain Size distributions in the present study highlighted a different pattern in the two 320 studied estuarine systems, i.e, a higher proportion of fine fractions under Oysters compared to the Reference, in 321 the Aber Benoît, but not in the Rivière d'Auray (table 4). A decrease in water circulation due to rearing 322 structures has usually been reported to explain the enhanced sedimentation beneath cultures (Kervella et al., 323 2010). In Aber Benoît, this phenomenon, associated with a relatively high density of oysters (39 tonnes per 324 hectar) may have increased the sedimentation of fine particles beneath Oysters in spite of the high current velocities generally occurring in this estuary (around $0.8-1.3 \mathrm{~m} \mathrm{~s}^{-1}$ ). At the Reference, located closer to the 326 channel than the oyster structures, the stronger currents (Dyers, 1989) generated by high tides may have dispersed the fine particles over a large area.

In the Rivière d'Auray, lower current velocities (around $0-0.4 \mathrm{~m} \mathrm{~s}^{-1}$ ) should have promoted silting under rearing structures and limited their dilution over the entire area. Our grain size data do not confirm this

330 hypothesis. This could be explained by the 15 times lower density of oysters in the Rivière d'Auray (2-3 tonnes 331 per hectar) than in the Aber Benoît. Moreover, low hydrodynamic conditions, favourable to water stagnation, 332 making them more sensitive to anthropological inputs, could well explain the presence of green macroalgae, 333 stranding regularly (Piriou et al., 1995), both under Oysters and at the Reference. These macroalgae, while 334 increasing both organic matter and fine particles in sediments (Argese et al., 1992) could mask the biodeposition 335 phenomenon under the rearing structures. Thus, macroalgae, and to a lesser extent, the transport of biodeposits 336 from Oyster to Reference, may also explain the absence of significant differences $(\mathrm{p}<0.01)$ in Orga-C, Chl a, Phaeopigments and Orga-P concentrations between the Oyster and Reference sites (figures 3 and 5). 
In contrast, in the Aber Benoît, macroalgae deposits remained fixed to the rearing structures. As a matter of fact, the distribution of organic matter indicators in the Aber Benoît (Orga-C, Total N (not shown), Chl a and Phaeopigment) indicated a significant organic enrichment beneath Oyster compared to the Reference (figure 3), especially in May and June $(\mathrm{n}=12 ; \mathrm{p}<0.01)$. The $\mathrm{Chl}$ a content of sediment beneath oysters in the Aber Benoit was probably enhanced by phytoplankton contained in the faeces and pseudofaeces of oysters, where a part of the Chl a has not been degraded (Barranget et al., 1994). Likewise, the increase in May and June of phaeopigments in sediment (figure 3) under Oysters could be due to bivalve metabolism as phaeopigments were shown to be linked to the feeding activity of molluscs (Barranget et al., 1997).

\section{V.2. Mineralization of buried organic matter : consequences for nutrient release}

Our data show common mineralization processes at all sites (1) but also a different fate of the buried organic matter between the two estuaries (2) and between reference and oyster sites (3). The intensity of mineralization is not always linked to organic matter levels in sediments as reported in other coastal shellfish areas (Mesnage et al., 2007).

(1) At both sites, mineralization of the buried organic matter followed the general sequence of early diagenetic reactions : oxygen was reduced in the surficial sediment (penetration depth lower than $5 \mathrm{~mm}$ ). Nevertheless, net $\mathrm{O}_{2}$ consumption rates (from about 2-3 $\mu \mathrm{mol} \mathrm{cm} \mathrm{d}^{-3}$ in September to 7-10 $\mu \mathrm{mol} \mathrm{cm} \mathrm{cm}^{-3} \mathrm{~d}^{-1}$ in May ; Andrieux-Loyer et al., in prep.) do not reveal significant differences in mineralization between Oyster cultures and References, both in the Aber Benoit and in the Rivière d'Auray. $\mathrm{O}_{2}$ consumption was followed by the reduction in nitrate, manganese oxides, iron oxides and sulfate. This induced seasonal accumulation of $\mathrm{NH}_{4}^{+}$,

$\mathrm{HPO}_{4}{ }_{4}^{2-}, \mathrm{Mn}^{2+}, \mathrm{Fe}^{2+}$ and $\mathrm{H}_{2} \mathrm{~S}$ in the sediment, especially in the Aber Benoît under Oysters (figures 7 and 8). In the Rivière d'Auray, these parameters also highlighted the typical behaviour of the Reference as described above, ie, higher concentrations at the Reference. The increase in $\mathrm{C} / \mathrm{N}$ (up to 9.6) and $\mathrm{C} / \mathrm{P}$ (up to 315) from June to September and with depth (figure 4), high particulate Orga-C to Chl a ratios ( $>200$; Table 4), and Chl a to $(\mathrm{Chl}$ a + pheophytin) ratio $\sim$ 0.2-0.4 (data not shown) confirmed mineralization processes.

(2) However, $\mathrm{COP} / \mathrm{Chl}$ a ratio- often used as an indicator of organic matter properties (Richard et al.,

364 1997) -also pointed out a significantly different pattern beneath Oyters between the two estuaries. The significantly higher $\mathrm{COP} / \mathrm{Chl}$ a ratios in the Rivière d'Auray compared to those in the Aber Benoit, suggested a 
concentrations of organic Carbon 1.5-2 times higher in surficial sediments $(0-3 \mathrm{~cm})$ than in the Aber Benoît

368 (table 4 ; figure 3), the concentrations of mineralization products (ammonium, sulfide and to a lesser extent,

369 phosphate; figure 8) as well as their fluxes (figure 9) were relatively similar to or significantly lower (especially

370 in June and July) than those reported in the Aber Benoit. We hypothesize that in the Rivière d'Auray there was a

371 weaker degradation bacterial activity due to the nature of the organic matter (fewer biodeposits) but also to that

372 of the bacterial community. Vibrio bacteria- particularly organotrophic- were more abundant in the Aber Benoit

373 than in the Rivière d'Auray (Azanddegbe, 2010). The coarser nature of the sediments in the Aber Benoit

374 compared to the Rivière d'Auray could also explain the different fate of the freshly deposited organic matter

375 beneath Oysters. The rapid degradation of organic matter was shown to occur in coarse, permeable sediments

376 (Bühring et al., 2006). In contrast, in fine-grained deposited sediments, remineralization could be delayed until

377 late summer (Boon and Duineveld, 1998).

378 Nevertheless, at the Reference sites, a more conventional pattern occurred with the intensity of 379 mineralization linked to organic matter levels in sediments. This was probably due to less difference in the 380 nature of organic matter, as shown by $\mathrm{COP} / \mathrm{Chl}$ a ratios in surficial sediments (table 4). In addition, surficial 381 Orga-C concentrations at the References were significantly higher in the Rivière d'Auray compared to the Aber 382 Benoît (up to 4.8 times higher, in August), which could mask different mineralization processes (table 4).

383 (3) A different fate of the buried organic matter was also observed between Oyster and Reference 384 sites, especially in the Aber Benoit. Despite relatively low enrichment in Orga-C in the superficial sediments 385 beneath Oyster compared to the Reference (a maximal factor around 1.5 in May 2008), fluxes of ammonia, 386 phosphate and sulfide could be respectively up to around 70,110 and 75 higher at the Oyster than at the 387 Reference sites (figure 9). This suggests an efficient and rapid degradation of organic matter underneath oysters.

388 This could not be explained by temperatures in the overlying and pore waters, similar for Oyster and Reference 389 (figure 2) but rather by the nature of biodeposits shown to be rapidly decomposed compared to other organic 390 material in coastal sediments (decay rates of phytoplankton and macroalgae 1.6 to 22 times lower than those of 391 biodeposits; Giles and Pilditch, 2006).

\section{V.3. Consequences for the phosphorus cycle}

The cycle of phosphorus in sediment is strongly linked to the cycle of deposition/mineralization of significantly modifies the phosphorus cycle through the interactions of $\mathrm{Fe}, \mathrm{S}$ and $\mathrm{P}$. 
398 1) and/or sulphate reduction (state 2) becomes the prominent process (Ekholm and Lehtoranta, 2012). In the 399 present study, low dissolved iron concentrations $\left(<50 \mu \mathrm{mol} \mathrm{l}^{-1}\right)$ and sulfide concentrations higher than 3400 $\mu$ mol $~^{-1}$ beneath oysters in June and July in the Aber Benoît (figure 11) highlighted a shift from a system governed by iron oxide reduction (Reference) to a system where sulphate reduction dominates (beneath oysters). According to Lehtoranta et al., (2009), a major factor causing this shift from state 1 to state 2 is an increase in the input of labile organic matter to the sediment. This is in agrement with the increase in labile organic matter beaneath oysters in the Aber Benoît (see § V.2).

The presence of free sulfide was shown to enhance the release of dissolved phosphate in slurry experiments (Heijs et al., 2000), whereas the addition of iron salts could temporarily prevent phosphate exchange to the overlying water (Smolder et al., 2001). In the Aber Benoît, beneath oysters, the highest sulfide concentrations generally corresponded to the highest phosphate concentrations and to the lowest dissolved iron (figures 7 and 8). The decrease in dissolved iron could be explained by the formation of iron-sulfide compounds $\left(\mathrm{FeS}, \mathrm{FeS}_{2}\right)$, which reduces adsorption sites for phosphate. Fe scavenging by hydrogen sulphide, -already reported in coastal systems (Boesen and Postma, 1988 ; Sundby et al., 1981)- has been shown to limit the upward transport of ferrous iron and subsequent re-precipitation of ferric iron at the oxic-anoxic boundary 413 (Hupfer and Lewandowski, 2008). Phosphate is then released into the overlying water, wheras precipitated Fe is 414 buried in the sediment. This decoupling of the Fe and P cycles -which occurs when sulphate reduction is the 415 predominant process- decreases the availability of oxic surficial sediment to retain P. In the Aber Benoit beneath 416 oysters, the significant correlations between sulfide and phosphate in the interstitial waters $\left(r^{2}=0.82 ; n=16\right)$ 417 and the absence of correlation between dissolved iron and phosphate concentrations $\left(r^{2}<0.01\right)$, especially in 418 June and July, as well as the significant increase in phosphate fluxes at the sediment-water interface at this 419 period, reinforced the idea of the decoupling of Fe and P cycles. In addition, the decrease in adsorption sites for phosphate as sulfide availability increased was in agreement with the general trend of Fe-P concentrations 421 decreasing with depth and from May to July in the Aber Benoît beneath oysters (figure 5).

423 water Fe:P $\left(\mathrm{Fe}^{2+} / \mathrm{HPO}_{4}{ }_{4}^{2-}\right)$ and N:P ratios $\left(\mathrm{NH}_{4}^{+} / \mathrm{HPO}_{4}{ }_{4}^{2-}\right)$ and controlled the phosphate flux at the sediment-

424 water interface. In coastal anoxic sediments such as those of the Aber Benoît and Rivière d'Auray, $\mathrm{O}_{2}$ and also 
$425 \mathrm{NO}_{3}{ }_{3}^{-}$are consumed in the first mm layers (see $\S$ V.2). Consequently, dissolved N/P ratios in pore water can be 426 represented by $\mathrm{NH}_{4}^{+} / \mathrm{HPO}_{4}{ }_{4}^{2-}$ ratios.

The ratio between dissolved ammonium and phosphate $\left(\mathrm{NH}_{4}^{+} / \mathrm{HPO}_{4}{ }_{4}^{2-}\right)$ can supply information about the processes of phosphate release and uptake in the sedimentary cores (Ruttenberg and Berner, 1993 ; Schuffert 429 et al., 1994). A constant ratio indicates a stoichiometric nutrient regeneration in which organic matter mineralization prevails. Variable ratios suggest that reactions of $\mathrm{P}$ removal or addition occur.

A decrease in molar ratio of dissolved $\mathrm{Fe} / \mathrm{P}$ can also indicate high liberation of phosphate in the pore waters whithout corresponding high dissolved $\mathrm{Fe}^{2+}$ release from sediment to pore water (Rozan et al., 2002 ;

433 Lehtoranta and Heiskanen, 2003).

At both studied sites, the lowest dissolved $\mathrm{Fe} / \mathrm{P}$ ratios (figure 10) corresponded to the highest concentrations in sulfide as $\mathrm{Fe}^{2+}$ decreased through FeS formation (Sundby et al., 1992 ; Anschutz et al., 1998)

436 and $\mathrm{HPO}_{4}{ }_{4}^{2-}$ increased due to desorption (figure 8). Moreover, according to Stumm (1992), when Fe-oxide- $\mathrm{PO}_{4}$ 437 complexes are destroyed, $\mathrm{PO}_{4}$ is solubilized while $\mathrm{Fe}^{2+}$ remains attached to the solid for some time. This could 438 also partly explain the decrease in dissolved Fe/P ratios in pore waters exhibiting temporary anoxia, as those of 439 in this study. At the same time, pore water N/P decreased (figure 10).

440 However, some other processes such as Auth-Ca-P formation could counterbalance the decrease in 441 dissolved Fe/P and N/P ratios in scavenging dissolved phosphate (Ruttenberg, 1992 ; Raimonet et al., 2013). The 442 enhanced liberation of pore water $\mathrm{HPO}_{4}{ }_{4}^{2-}$ arising from Orga-P mineralization or from Fe-P dissolution should 443 promote Auth-Ca-P precipitation (Slomp et al., 1996º Raimonet et al., 2013). In the Aber Benoît, Auth-Ca-P 444 precipitation and Fe-P precipitation in superficial sediments in May (beneath oysters) and in June and at the end 445 of July in deeper layers (Reference), could partly explain the sharp rise in the ratio between dissolved 446 ammonium and phosphate $\left(\mathrm{NH}_{4}^{+} / \mathrm{HPO}_{4}{ }_{4}^{2-}\right)$ and dissolved iron and phosphate $\left(\mathrm{Fe}^{2+} / \mathrm{HPO}_{4}{ }_{4}^{2-}\right)$ during these periods 447 (respectively up to 70 and to 27). High N/P ratios indicated that mineralization alone cannot explain nutrient 448 profiles and that $\mathrm{HPO}_{4}{ }_{4}^{2-}$ removal and/or $\mathrm{NH}_{4}^{+}$formation must have taken place (Ruttenberg and Berner, 1993). 
449 The formation of $\mathrm{NH}_{4}^{+}$by dissimilatory $\mathrm{NO}_{3}^{-}$reduction (DNRA) in anoxic conditions already observed in 450 anoxic coastal sediments could also increase $\mathrm{NH}_{4}^{+} / \mathrm{HPO}_{4}{ }_{4}^{2-}$ ratios (Gardner et al., 2002). In contrast, in the Rivière d'Auray, the $\mathrm{NH}_{4}^{+} / \mathrm{HPO}_{4}{ }_{4}^{2-}$ ratios, close to or lower than 16 , indicated that mineralization processes and Fe-P dissolution prevailed. This was in accordance with the low $\left(<3 \mu \mathrm{mol} \mathrm{g}^{-1}\right)$ and almost Auth-Ca-P constant concentrations over time (figure 5) and indicated that in this area, Auth-Ca-P probably did not contribute to the enrichment of the water column.

In the two areas, Auth-Ca-P -unlike Fe-P and Orga-P- was not significantly influenced by oyster cultures. However, in the Aber Benoît, the significant seasonal variations in Auth-Ca-P (Figure 5) indicated that this form of phosphorus- in the same way as Fe-P and Orga-P-could temporally behave as a sink for phosphate, then acting as a "time bomb" that could induce a modification in the trophic resource. In fact, if Auth-Ca-P has been generally considered as a sink for P (Ruttenberg and Berner, 1993 ; Andrieux-Loyer et al., 2008), it has also been shown that it could be redissolved (Spagnioli and Bergamini, 1997).

The precipitation and dissolution of Auth-Ca-P in sediments is controlled by $\mathrm{pH}$ and phosphate concentrations. Auth-Ca-P is precipitated at high $\mathrm{pH}$ and high $\mathrm{HPO}_{4}{ }_{4}^{2-}$ activity (Stumm and Morgan, 1970). In this study, favorable conditions of Auth-Ca-P precipitation could occur after the sedimentation of labile organic matter beneath oysters (increase in phosphate concentrations due to mineralization processes), whereas the decrease in $\mathrm{pH}$ following mineralization processes could promote Auth-Ca-P re-dissolution. $\mathrm{pH}$ lower than 7-7.5 -already observed in coastal sediments- were shown to cause dissolution of weakly crystalline apatite (Stumm and Morgan, 1970 ; Stumm, 1992 ; Golterman, 1998).

Due to the complexity of processes governing phosphate fluxes at the sediment-water interface, some

authors have suggested using dissolved $\mathrm{Fe} / \mathrm{P}\left(\mathrm{Fe}^{2+} / \mathrm{HPO}_{4}{ }_{4}^{2-}\right)$ ratios as an indicator of phosphate release in lake or marine sediments (Geurts et al., 2008 ; Jensen et al., 1992 ; Lehtoranta and Heiskanen, 2003). between dissolved iron and phosphate in surficial sediments. As freshly precipitated ferric oxides and 473 phosphorus appear to form an aggregate structure with 2 moles of iron per each mole of phosphorus (Sugawara 474 et al., 1957 ; Golterman, 1995), some authors have shown that the molar ratio of dissolved ferrous iron to 475 dissolved phosphorus must be at least 2 in the pore water to ensure that newly formed ferric oxides can bind the 
released phosphate (Gunnars et al.,1997). Thus, ratios lower than 2 would mean that there is no enough iron to capture all the pore water phosphate in the superficial oxic layer, which would result in an increased benthic efflux of phosphate.

These ratios were generally lower in anaerobic marine systems than in freshwater systems due to high sulphate concentrations which can serve as a souce for sulphate reduction in conditions of a good supply of labile organic matter (Gunnars and Blomqvist, 1997 ; Zak et al., 2006).

In the Aber Benoit, maximal phosphate fluxes in June and July beneath oysters, corresponded to dissolved Fe/P molar ratios in surficial sediments significantly lower than the theoretical value of 2 mol:mol, corresponding to the complexation of $\mathrm{Fe}(\mathrm{OOH})$ with phosphate (figure 12). This indicated that in the Aber Benoît beneath oysters during the summer period, the available iron was in too short supply to bind all upward diffusing phosphate at the sediment water-interface. This induced a higher liberation of phosphate towards the water column (figures 9 and 12). At the other periods and at the Reference, the pore water ratios higher than 2 mol:mol indicated that there was enough dissolved $\mathrm{Fe}^{2+}$ to form a superficial $\mathrm{Fe}^{3+}$ oxide layer which could retain the up-ward diffusing phosphate. In the Rivière d'Auray, the shift from state 1 to state 2 (figure 12) was less marked, probably due to the nature of the organic matter, i.e, mostly macroalgae, less labile than biodeposits (see $\S$ V.2). Nevertheless, at the Reference, the highest phosphate flux in May corresponded to the lowest Fe/P ratio $(<2 \mathrm{~mol}: \mathrm{mol})$, and to the highest sulfide and phosphate concentrations (figure 8$)$.

\section{CONCLUSION}

Our results highlight the influence of oyster cultures on biogeochemical processes in the sediments of the Aber Benoît, especially concerning the phosphorus cycle. In contrast, in the Rivière d'Auray, the occurrence of macroalgae at both Reference and Oyster sites masked the impact of oysters.

The intensity of organic matter mineralization beneath oysters, as highlighted by diffusive fluxes of mineralization products, was lower in the Rivière d'Auray than in the Aber Benoît despite organic matter levels being 1.5-2 times higher. This could be explained by the less labile nature of organic matter in the Rivière d'Auray (fewer biodeposits) than in the Aber Benoît, as shown by COP/ Chl a ratios.

In the Aber Benoît, the increase in labile organic matter (ie biodeposit) beneath oysters seasonally increased outfluxes of ammonium, sulfide and phosphate due to mineralization processes. The enhanced phosphate availability was also explained by the less effective scavenging of phosphate by iron hydroxides, as sulfide formed iron sulfide compounds. This release of phosphate appeared to increase significantly when 
dissolved Fe/P ratios dropped below a value of 2 . This additional seasonally released $\mathrm{P}$ may significantly increase the biologically available pool of $\mathrm{P}$ in the water, thus modifying the trophic resource. Oyster cultures could consequently lead to long term modifications in the capacity of the sediment in scavenging/liberating phosphate.

\section{ACKNOWLEDGEMENTS}

This work was financially supported by the Brittany Region and the French Research Institute for Exploitation of the Sea (IFREMER). We sincerely thank two anonymous reviewers for their insightful critical comments and suggestions.

\section{REFERENCES}

Aminot A, Kérouel R (2004) Hydrologie des écosystèmes marins. Paramètres et anlayses. Ed. Ifremer, $336 \mathrm{p}$.

Aminot A, Kérouel R, Coverly, SC (2009) Nutrients in Seawater Using Segmented Flow Analysis. In : O. Wurl (Ed), Practical Guidelines for the Analysis of Seawater, Inc. Boca Raton, 2009, pp. 143-178

Andrieux-Loyer F, Aminot A (2001) Phosphorus forms related to sediment grain size and geochemical characteristics in French Coastal Areas. Estuarine Coastal and Shelf Science 52: 617-629

Andrieux-Loyer F, Philippon X, Bally G, Kérouel R, Youenou A, Le Grand J (2008) Phosphorus dynamics and bioavailability in sediments of the Penzé Estuary (NW France): in relation to annual P-fluxes and occurrences of Alexandrium Minutum. Biogeochemistry 88: 213-231

Anschutz P, Zhong A, Sundby B, Mucci A, Gobeil C (1998) Burial efficiency of phosphorus and the geochemistry of iron in continental margin sediments. Limnology and Oceanography 43: 53-64

Anschutz P, Chaillou G, Lecroart P (2007) Phosphorus diagenesis in sediment of the Thau lagoon. Estuarine Coastal and Shelf Science 72(3): 447-456

Argese E, Cogoni G, Zaggia L, Zonta R, Pini R (1992) Study on Redox State and Grain Size of Sediments in a Mud Flat of the Venice Lagoon. Environmental Geology and water sciences. 20: 35-42

Aspila KI, Agemian H, Chau AS (1976) A semi-automated method for the determination of inorganic, organic and total phosphate in sediments. Analyst, 101:187-197 
Azandegbe A (2010) Etude de la structure des communautés bactériennes du sediment et de l'écologie de

Vibrio aestuarianus pathogène de l'huitre creuse Crassostrea gigas dans deux sites ostréicoles. Thèse de

Doctorat, Univ-Brest, 256 pp.

Barranget C, Alliot E, Plante-Cuny MP (1994) Benthic microphytic activity at two Mediterranean

shellfish cultivation sites with reference to benthic fluxes. Oceanologica Acta, 17 (2): 211-221

Barranget C (1997) The Role of Microphytobenthic Primary Production in a Mediterranean Mussel

Culture Area. Estuarine Coastal and Shelf Science 44: 753-765

Beller P, Pomerol P (1977) Eléments de Géologie. Armand Colin, Paris, 528 pp.

Berelson WM, Heggie D, Longmorec A, Kilgore T, Nicholsonc G, Skyring G (1998) Benthic nutrient recycling in Port Phillip Bay, Australia. Estuarine, Coastal and Shelf Science 46: 917-934

Boon AR, Duineveld G.C.A (1998) Chlorophyll a as a marker for bioturbation and carbon flux in

Boudreau BP (1996) The diffusive tortuosity of fine-grained unlithified sediments. Geochemica

Bühring SI, Ehrenhauss S, Kamp A, Moodley L, Witte U (2006) Enhanced benthic activity in sandy

Dyers K (1989) Estuarine flow interaction with topography- Lateral and longitudinal effects in Estuarine circulation. In: Neilson B, Kuo A and Brubaker J (eds) Estuarine circulation. Humana.

Ekholm P, Lehtoranta J (2012) Does control of soil erosion inhibit aquatic eutrophication ? Journal of

Fonselius S, Dyrssen D, Yhlen B (1999) Determination of hydrogen sulfide. Methods of seawater

560 Analysis, $3^{\text {rd }}$ extended edn (Grasshoff, K., Kremling, K. \& Ehrhardt, M., eds), pp. 91-100, Wiley-VCH, 561 Weinheim. 
Forrest BM, Creese RG (2006) Benthic impacts of intertidal oyster culture, with consideration of

563

564

565

566

567

568

569

570

571

572

573

574

575

576

577

578

579

580

581

582

583

584

585

586

587

588

taxonomic sufficiency. Environmental Monitoring and Assessment 112: 159-176

Gagnaire B, Soletchnik P, Madec P, Geairon P, Le Moine O. Renault T (2006) Diploid and triploid oysters, Crassostrea gigas (Thunberg), reared at two heights above sediment in Marennes-Oleron Basin, France: difference in mortality, sexual maturation and hemocyte parameters. Aquaculture 254: 606-616

\author{
Gaertner-Mazouni N, Lacoste E, Bodoy A, Peacock L, Rodier M, Langlade M, Orempuller J, Charpy L
}

(2012) Nutrient fluxes between water column and sediments: Potential influence of the pearl oyster culture.

Marine Pollution Bulletin 65(10-12): 500-505.

Giles H, Pilditch CA, Bell DG (2006) Sedimentation from mussel (Perna canaliculus) culture in the Firth of Thames, New Zealand: Impact on sediment oxygen and nutrient fluxes. Aquaculture 261(1): 125-140

Giles H, Pilditch CA (2006) Effects of mussel (Perna canaliculus) biodeposit decomposition on benthic respiration and nutrient fluxes. Marine Biology 150: 261-271

Geurts JJM, Smolders AJP, Verhoeven JTA, Roelofs JGM, Lamers LPM (2008) Sediment Fe:PO4 ratio as a diagnostic and prognostic tool for the restoration of macrophyte biodiversity in fen waters. Freshwater Biology 53: 2101-2116

Golterman HL (1995). Theorical aspects of the adsorption of ortho-phosphate onto iron hydroxide. Hydrobiologia, 315: 59-68.

Golterman, H. L., 1998.The distribution of phosphate over ironbound and calcium-bound phosphate in stratified sediments. Hydrobiologia 364: 75-81.

Gunnars A, Blomqvist S (1997) Phosphate exchange across the sediment-water interface when shifting from anoxic to oxic conditions-an experimental comparison of freshwater and brackish-marine systems. Biogeochemistry 37: 203-226

Heijs S K, Azzoni R, Giordani G, Jonkers HM, Nizzoli D, Viaroli P, van Gemerden H (2000) Sulfideinduced release of phosphate from sediments of coastal lagoons and the possiblerelation to the disappearance of Ruppia sp. Aquatic Microbial Ecology 23: 85-95

Hupfer M, Lewandowski J (2008) Oxygen Controls the Phosphorus Release from Lake Sediments - a Long-Lasting Paradigm in Limnology. International Review of Hydrobiology 93(4/5): 415-432 
Hyun J, Kim S, Mok J, Lee JS, An S, Lee W, Jung R (2013) Impacts of long-line aquaculture of pacific oysters (crassostrea gigas) on sulfate reduction and diffusive nutrient flux in the coastal sediments of jinhaetongyeong, korea. Marine Pollution Bulletin 74(1):187-98

Jensen HS, Kristensen P, Jeppesen E, Skytthe A (1992) Iron:phosphorus ratio in surface sediment as an indicator of phosphate release from aerobic sediments in shallow lakes. Hydrobiologia 235/236: 731-743 Jensen HS, Bo Thamdrup (1993) Iron-bound phosphorus in marine sediments as measured by bicarbonate-dithionite extraction. Hydrobiologia 253: 47-59

Kervella Y, Germain G, Gaurier B, Facq JV, Cayocca F, Lesueur P (2010) Experimental study of the near-field impact of an oyster table on the flow. European Journal of Mechanics-B/Fluids. 29(1): 32-42 Krom MD, Berner RA (1980) Adsorption of phosphate in anoxic marine sediments. Limnology and Oceanography 25: 797-806

Krom MD, Berner RA (1981) The diagenesis of phosphorus in a nearshore marine sediment. Geochimica et Cosmochimica Acta 45: 207-216

Larsonneur C (1971) Manche Centrale et Baie de Seine: géologie du substratum et des dépôts meubles. Thèse d'Etat de l'université de Caen, $n^{\circ}$ A.O. 5404, 387 pp.

Lehtoranta J, Heiskanen AS (2003) Dissolved iron:phosphate ratio as an indicator of phosphate release to oxic water of the inner and outer coastal Baltic sea. Hydrobiologia 492: 69-84

Lehtoranta J, Ekholm P, Pitkänen H (2009) Coastal Eutrophication Threshold: A Matter of sediment Microbial Processes. Ambio 38(6): 303-308 Lorenzen CJ (1967) Determination of chlorophyll and pheopigments: spectrophotometric equations. Limnology and Oceanography 12: 343-346

Li YH, Gregory S (1974) Diffusion of ions in sea water and in deep-sea sediments. Geochemica Cosmochimica Acta 33: 703-714

Mallet AL, Carver CE, Landry T (2006) Impact of suspended and off-bottom eastern oyster culture on the benthic environment in eastern Canada. Aquaculture 255: 362-373

Matijevic S, Grozdan K, Kljakovic-Gaspic Z, Bogner D (2008) Impact of fish farming on the distribution of phosphorus in sediments in the Middle Adriatic area. Marine pollution Bulletin 56: 535-548

Mazouni N (2004) Influence of suspended oyster cultures on nitrogen regeneration in a coastal lagoon (Thau, France). Marine Ecological Progress Series, 276: 103-113. 

dynamics at the sediment water-interface in a Mediterranean lagoon (Thau, France): Influence of biodeposition by shellfish farming activities. Marine Environmental Research 63: 257-277 $252 \mathrm{pp}$.

Nizzoli D, Welsh DT, Fano EA, Viaroli P (2006) . Impact of clam and mussel farming on benthic metabolism and nitrogen cycling, with emphasis on nitrate reduction pathways. Marine Ecology Progress Series 315:151-165

Nugues MM, Kaiser MJ, Spencer BE, Edwards DB (1996) Benthic community changes associated with intertidal oyster cultivation. Aquatic Resources 27: 913-924

Pietros JM, Rice, MA (2003) The impacts of aquacultured oysters, Crassostrea virginica (Gmelin, 1791) on water column nitrogen and sedimentation: results of a mesocosm study. Aquaculture 220: 407-422.

Piriou JY, Chapron V, Annezo JP (1995) Mesure des flux nutritifs et inventaire d'algues vertes en 1995. Précontrat baie « Golfe du Morbihan ». Ifremer-DEL-n5-19, 26 pp. suspended matter and sediment. Archiv Für Hydrobiologie Beiheft Ergebnis Limnologie 30: 98-103. and Si cycles. Biogeochemistry 115(1-3): 399-417

Resing JA, Mottl MJ (1992) Determination of manganese in seawater using flow injection analysis with on-line preconcentration and spectrophotometric detection. Analytical Chemistry 64: 2682-2687

Richard P, Riera P, Galois R (1997) Temporal variations in the chemical and carbon isotop compositions 640 of marine and terrestrial organic inputs in the Bay of Marennes-Oléron, France. Journal of Coastal Research 13: $641 \quad 879-889$ sediments of a shallow coastal bay: Implications for sediment nutrient release and benthic macroalgal blooms. Limnology and Oceanography 47(5): 1346-1354. 
Sarradin P.M, Le Bris N, Le Gall C, Rodier O (2005) Fe analysis by the ferrozine method : adaptation to

FIA towards in situ analysis in hydrothermal environment. Talanta 66: 1131-1138

Sahling H, Rickert D, Lee RW, Linke P, Suess E (2002) Macrofaunal community structure and sulfife flux at gas hydrate deposits from the Cascadia convergent margin, NE Pacific. Marine Ecology Progress Series 231: 121-138.

Samain JF, McCombie H, Eds (2007) Summer mortalities of Pacific oyster Crassostrea gigas, The Morest Project. Ed. Ifremer/Quae, 332 P. $1179-1205$ from phosphate-enriched sediments by adding various iron compounds. Biogeochemistry $54: 219-228$ to environmental rearing conditions. Journal of Shellfish Research 24: 197-207 Recherche Océanographique $9: 38-40$

Spagnoli F, Bergamini MC (1997) Water-sediment exchange of nutrients during early diagenesis and resuspension of anoxic sediments from the Northern Adriatic Sea Shelf. Water, air and Soil Pollution 99: 541556 sulfate reduction. Chem. Inst. Fac. Sci. Nagoya Univ. 5: 60-67. phosphorites off western Mexico. Geochimica et Cosmochimica Acta 58: 5001-5010. Limnology and Oceanography 37: 1129-1145 in Natural Waters. Wiley Intersciences, New York, London, Toronto: 583 pp. 


\section{Table 1}

684 Main characteristics of Aber Benoît and Rivière d'Auray

685

\begin{tabular}{|c|c|c|}
\hline & Aber Benoît & Rivière d'Auray \\
\hline Location & $\begin{array}{l}\text { North-west Brittany } \\
4^{\circ} 36^{\prime} \mathrm{W} \text { and } 48^{\circ} 36^{\prime} \mathrm{N}\end{array}$ & $\begin{array}{c}\text { Gulf of Morbihan } \\
\text { South Britanny } \\
2^{\circ} 58^{\prime} \mathrm{W} \text { and } 47^{\circ} 36^{\prime} \mathrm{N}\end{array}$ \\
\hline Catchment area & $140 \mathrm{~km}^{2}$ & $800 \mathrm{~km}^{2}$ \\
\hline Anthropic influence & + & +++ \\
\hline $\begin{array}{c}\text { Oyster culture } \\
\text { Annual production/area }\end{array}$ & $1500 t / 38$ ha & $4500 t / 1635$ ha \\
\hline Depth at zero tide & $14 \mathrm{~m}$ & $20 \mathrm{~m}$ \\
\hline Mean tidal range & $6 \mathrm{~m}$ & $5 \mathrm{~m}$ \\
\hline Sea-water current & $0.8-1.3 \mathrm{~m} \mathrm{~s}^{-1}$ & $0-0.4 \mathrm{~m} \mathrm{~s}^{-1}$ \\
\hline Sediment & Grey sandy mud & Black sandy mud \\
\hline
\end{tabular}




\section{Table 2}

714 Sequential extraction method for phosphorus forms in sediments; Adsorbed and iron-oxide bound P 715 (Fe-P) and Authigenic calcium bound P (Auth-Ca-P) after Psenner, 1988 ; Ruttenberg, 1990 ; Slomp, 1996a and Organic phosphorus (Orga-P ; Aspila, 1992).

\begin{tabular}{|c|c|c|}
\hline Step & Extractant and Protocol & Phase extracted \\
\hline $\begin{array}{l}\text { I) Adsorbed + iron- } \\
\text { bound }\end{array}$ & $\begin{array}{l}0.1 \mathrm{~mol}^{-1} \text { Dithionite-Bicarbonate } \\
\text { (DB) }, 8 \mathrm{~h}, 20^{\circ} \mathrm{C}\end{array}$ & $\begin{array}{l}\text { Exchangeable or loosely sorbed P + } \\
\text { easily reducible Fe-bound P }\end{array}$ \\
\hline $\begin{array}{l}\text { II) Authigenic } \\
\text { (Auth-Ca-P) }\end{array}$ & $\begin{array}{l}\text { a) } 1 \mathrm{~mol} \mathrm{l}^{-1} \mathrm{Na} \text {-acetate buffer } \\
\left(\mathrm{pH}=4,6 \mathrm{~h}, 20^{\circ} \mathrm{C}\right) \\
\text { b) washing with } 1 \mathrm{~mol}^{-1} \mathrm{MgCl}_{2} \text {, } \\
\left(\mathrm{pH}=8,0.5 \mathrm{~h}, 20^{\circ} \mathrm{C}\right)\end{array}$ & $\begin{array}{l}\text { Carbonate fluoroapatite }(\mathrm{CFA})+ \\
\text { biogenic hydroxyapatite }+\mathrm{CaCO}_{3} \text {-bound } \\
\text { P }\end{array}$ \\
\hline III) Organic* & $\begin{array}{l}\text { a) } 1 \text { mol } 1-1 \mathrm{HCl} \text { treatment } \\
\text { overnight (inorganic } \mathrm{P} \text { ) } \\
\text { b) Ash at } 550^{\circ} \mathrm{C} \text {, then } 1 \mathrm{~mol} \\
1^{-1} \mathrm{HCl} \text { treatment overnight } \\
\text { (total } \mathrm{P} \text { ) }\end{array}$ & Organic P (Total P -inorganic P) \\
\hline
\end{tabular}


Table 3

Ammonium, phosphate and sulfide concentrations in Overlying Water $(\mathrm{OW})$ and pore water used in diffusive flux calculations both in Aber Benoît and Rivière d'Auray.

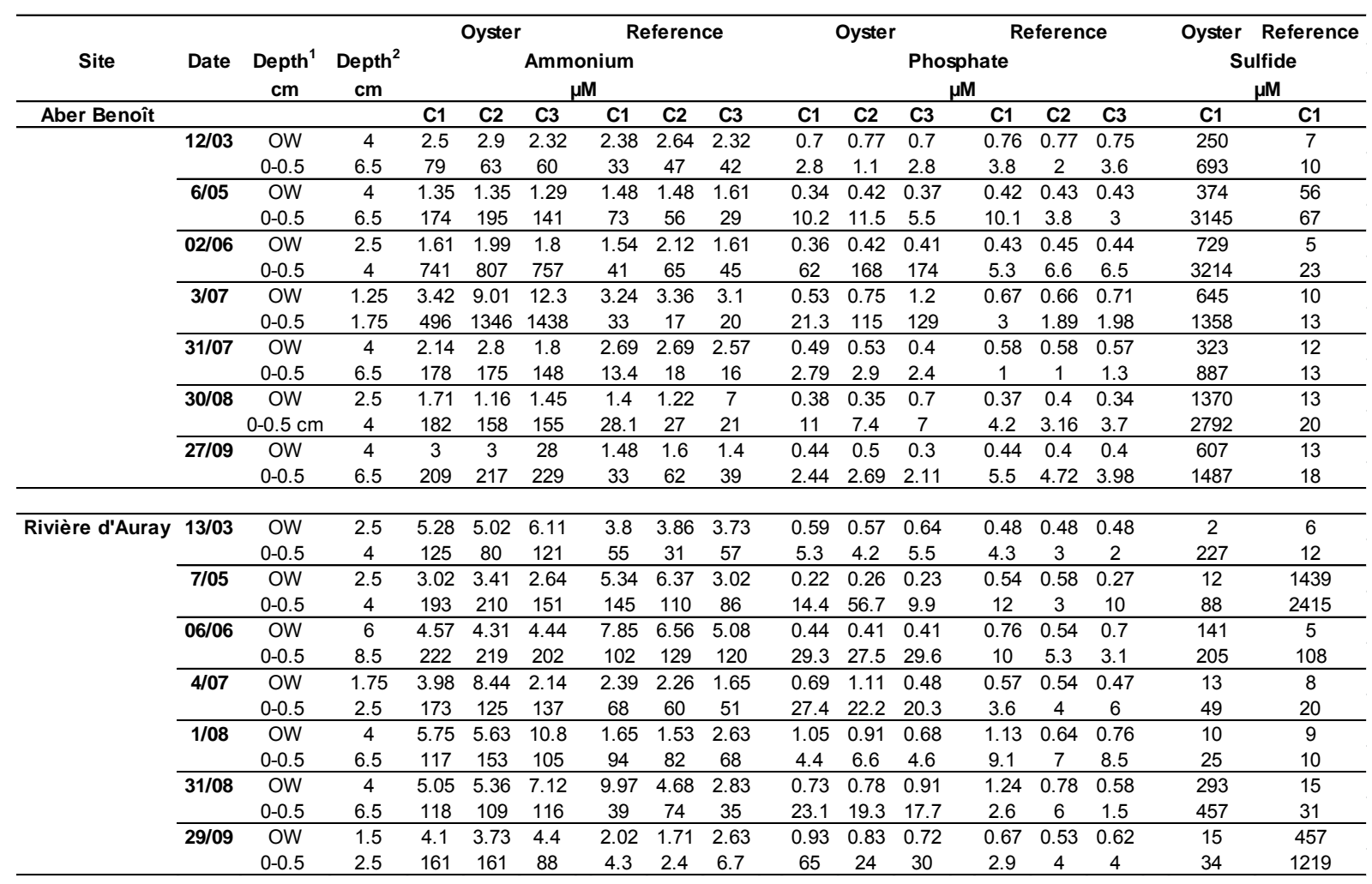

Units are in $\mu \mathrm{mol} l^{-1 .}$ 


\begin{tabular}{|c|c|c|c|c|}
\hline \multirow{2}{*}{ Study site } & \multicolumn{2}{|c|}{ Aber Benoît } & \multicolumn{2}{|c|}{ Rivière d'Auray } \\
\hline & Under Oysters & Reference & Under Oysters & Reference \\
\hline $\mathrm{n}$ & 31 & 31 & 33 & 33 \\
\hline $\begin{array}{c}\text { Granulometry } \\
\text { Silt + Clay }(\%)\end{array}$ & $34(3)$ & $25(5)$ & $67(4)$ & $70(5)$ \\
\hline Porosity $(\%)$ & $65(5)$ & $60(3)$ & $81(2)$ & $82(2)$ \\
\hline $\mathrm{C}(\mu \mathrm{mol} \mathrm{g}-1)$ & $950(333)$ & $764(246)$ & $1426(753)$ & $1728(279)$ \\
\hline $\mathrm{N}(\mu \mathrm{mol} g-1)$ & $139(40)$ & $109(39)$ & $223(53)$ & $270(50)$ \\
\hline $\begin{array}{c}\text { Orga-P }(\mu \mathrm{mol} \text { g- } \\
1)\end{array}$ & $3.8(1.4)$ & $3.0(1.3)$ & $5.2(1.6)$ & $6.2(1.9)$ \\
\hline $\mathrm{C} / \mathrm{N}$ & $\mathbf{8}(0)$ & $7(1)$ & $7(0)$ & $7(0)$ \\
\hline $\mathrm{C} / \mathrm{P}(\mathrm{COP} / \mathrm{POP})$ & $250(64)$ & $271(95)$ & $326(108)$ & $314(118)$ \\
\hline $\mathrm{N} / \mathrm{P}$ & $39(26)$ & $34(16)$ & $49(15)$ & $47(16)$ \\
\hline $\mathrm{COP} / \mathrm{Chl} \mathrm{a}$ & $694(250)$ & $787(330)$ & 1459 (785) & $1036(540)$ \\
\hline
\end{tabular}

Mean (bold type) and standard deviation (in parentheses) $n=$ number of observations

Table 4

Surficial sediment (in the top $3 \mathrm{~cm}$ ) characteristics at each study site over the study period. 
810 Figure 1. Study areas. A) Main situation ; $\mathrm{B}_{1}$ ) The Aber Benoit ; $\mathrm{B}_{2}$ ) The Rivière d'Auray.

812 Figure 2. Summary of overlying physical-chemical water properties (temperature, salinity, pH) in Aber Benoît

813 (1a) and in Rivière d'Auray (1b) during the study period (2007-2008). (O: beneath Oyster ; R: Reference).

814 Salinity is expressed on the PSS78 scale.

815 Figure 3. Organic Carbon (Orga-C) and Phaeopigments + Chlorophyll a (Chl a) seasonal distributions in 816 sediments (2007-2008) in the Aber Benoît and in the Rivière d'Auray both under Oysters and at Reference sites. 817 The concentration units are in $\mu \mathrm{mol} \mathrm{g}^{-1}$ for Orga-C and $\mu \mathrm{g} \mathrm{g}^{-1}$ for Phaeopigments and $\mathrm{Chl} \mathrm{a}$.

Figure 4. Orga C/N, Orga C/P seasonal distributions in sediments (2007-2008) in the Aber Benoît and in the Rivière d'Auray both under Oysters and at Reference sites.

Figure 5. Phosphorus forms (adsorbed and iron-oxide bound P (Fe-P), Organic P (Orga-P), Authigenic Calcium bound P (Auth-Ca-P) seasonal distributions in sediments (2007-2008) in the Aber Benoit and in the Rivière d'Auray both under Oysters and at Reference sites. The concentrations units are in $\mu \mathrm{mol} g-1$.

825

826 Figure 6. Oxygen microprofiles $\left(\mu \mathrm{mol}^{-1}\right.$ ) acquired by microelectrodes in function of depth (mm) during the study period in the Aber Benoît and in the Rivière d'Auray both under Oysters and at Reference sites.

828 Figure 7. Manganese $\left(\mathrm{Mn}^{2+}\right)$ and iron $\left.\mathrm{Fe}^{2+}\right)$ seasonal distributions in pore water sediments (2007-2008) in the Aber Benoit and in the Rivière d'Auray both under Oysters and at Reference sites. The concentration units are in $830 \mu \mathrm{mol} \mathrm{l}^{-1}$.

831 Figure 8. Ammonium $\left(\mathrm{NH}_{4}^{+}\right)$, phosphate $\left(\mathrm{HPO}_{4}{ }_{4}^{2-}\right)$ and sulfide $\left(\mathrm{HS}^{-}\right)$seasonal distributions in pore water

832 sediments (2007-2008) in the Aber Benoît and in the Rivière d'Auray both under Oysters and at Reference sites. The concentration units are in $\mu \mathrm{mol} 1^{-1}$

835 Figure 9. Seasonal variations of mean diffusive fluxes (Phosphate, Ammonium, Sulfide) in the Aber Benoît and

836 in the Rivière d'Auray both under Oysters and at Reference sites. Diffusive fluxes are determined from three cores for nutrients and from one core for sulfide and are expressed in $\mu \mathrm{mol} \mathrm{m}^{-2} h^{-1}$. Coefficients of variation ranged between 5-20\%. In order to facilitate comparisons between Aber Benoît and Rivière d'Auray, the same scale was used for each study area. 
840 Figure 10. Dissolved N/P and Fe/P ratios seasonal distributions in pore water sediments (2007-2008) in the Aber 841 Benoît and in the Rivière d'Auray both under Oysters and at Reference sites.

842 Figure 11. Sulfide (HS-), phosphate $\left(\mathrm{HPO}_{4}{ }_{4}^{2-}\right)$, dissolved iron $\left(\mathrm{Fe}^{2+}\right)$ and nitrate $\left(\mathrm{NO}_{3}^{-}\right)$profiles over depth in

843 June in the Aber Benoît at the Reference (1) and beneath Oysters (2). Concentrations are expressed in $\mu$ mol $1^{-1}$.

844 Figure 12. Dissolved Fe:P ratios in surface layer of pore water and diffusive fluxes of phosphate $\left(\mu \mathrm{mol} \mathrm{m} \mathrm{m}^{-2}\right)$.

845 Vertical dotted line represents theorical molar dissolved Fe:P ratio (2 mol:mol). For clarifying, sampling dates

846 are only indicated for the most characteristics results.

847

848

849

850

851

852

853

854

855

856

857

858

859

860

861

862

863

864

865

866

867 
874

875

876

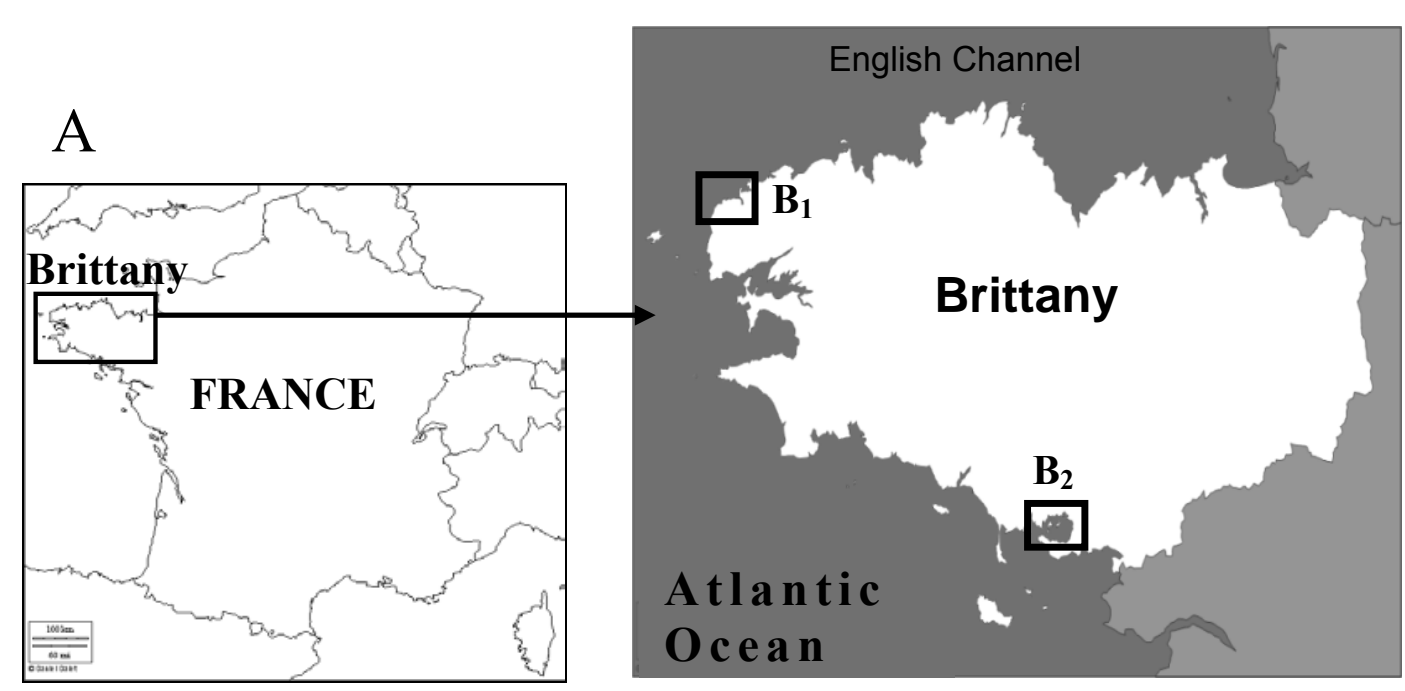

878

879

$\mathrm{B}_{1}$

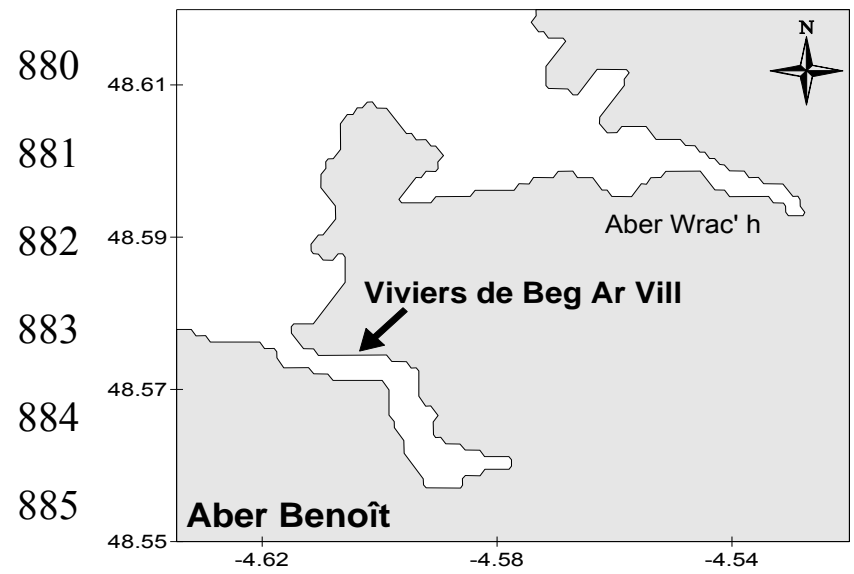

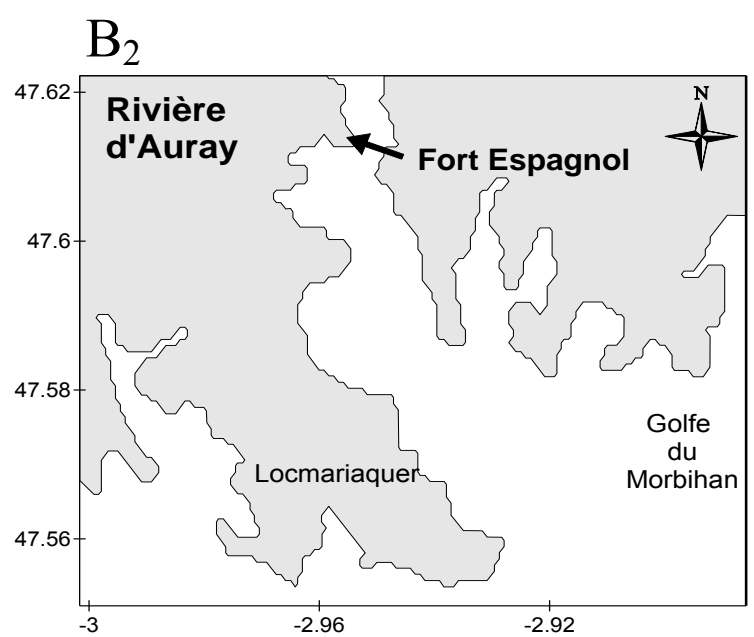

886

887

888 

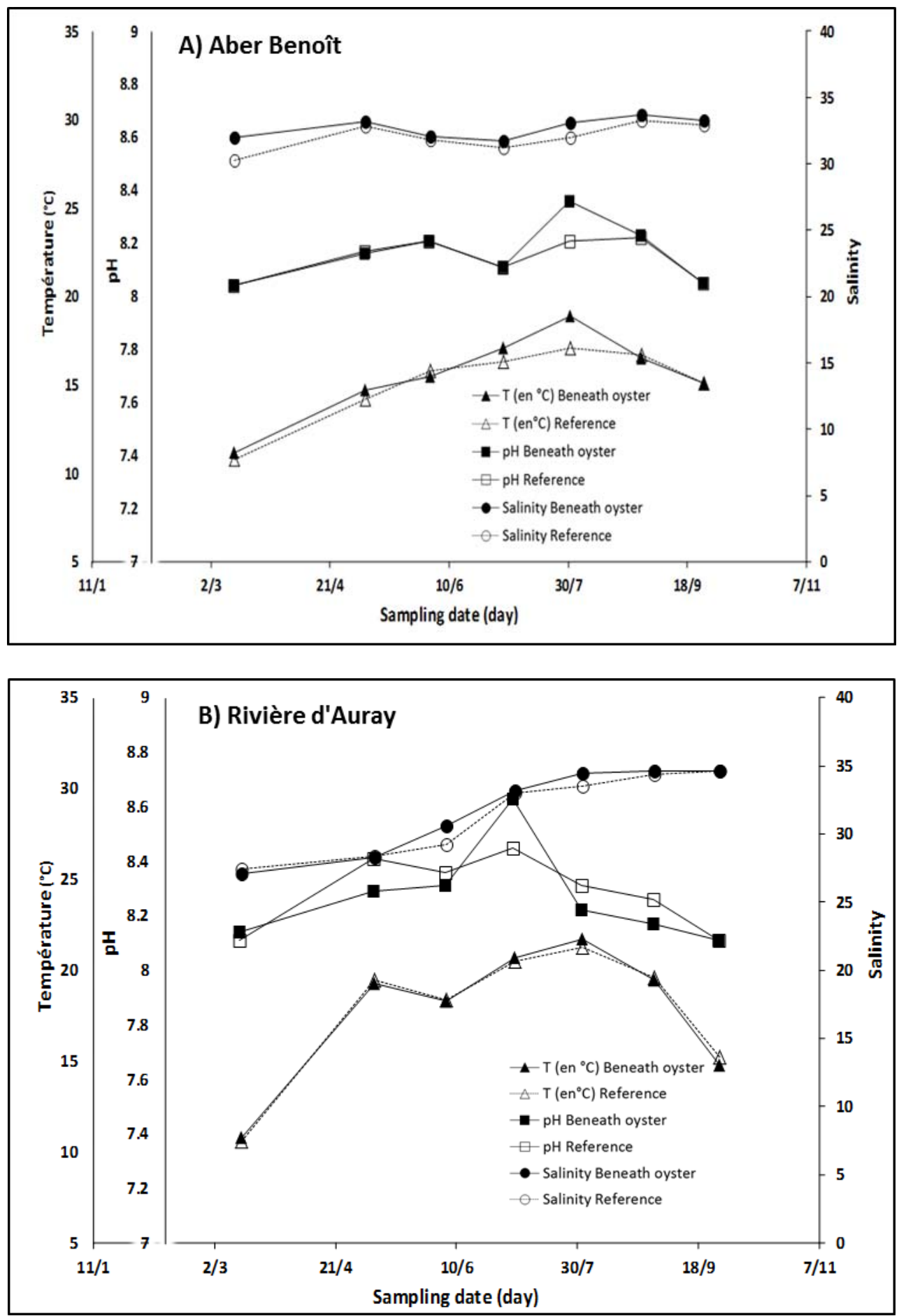

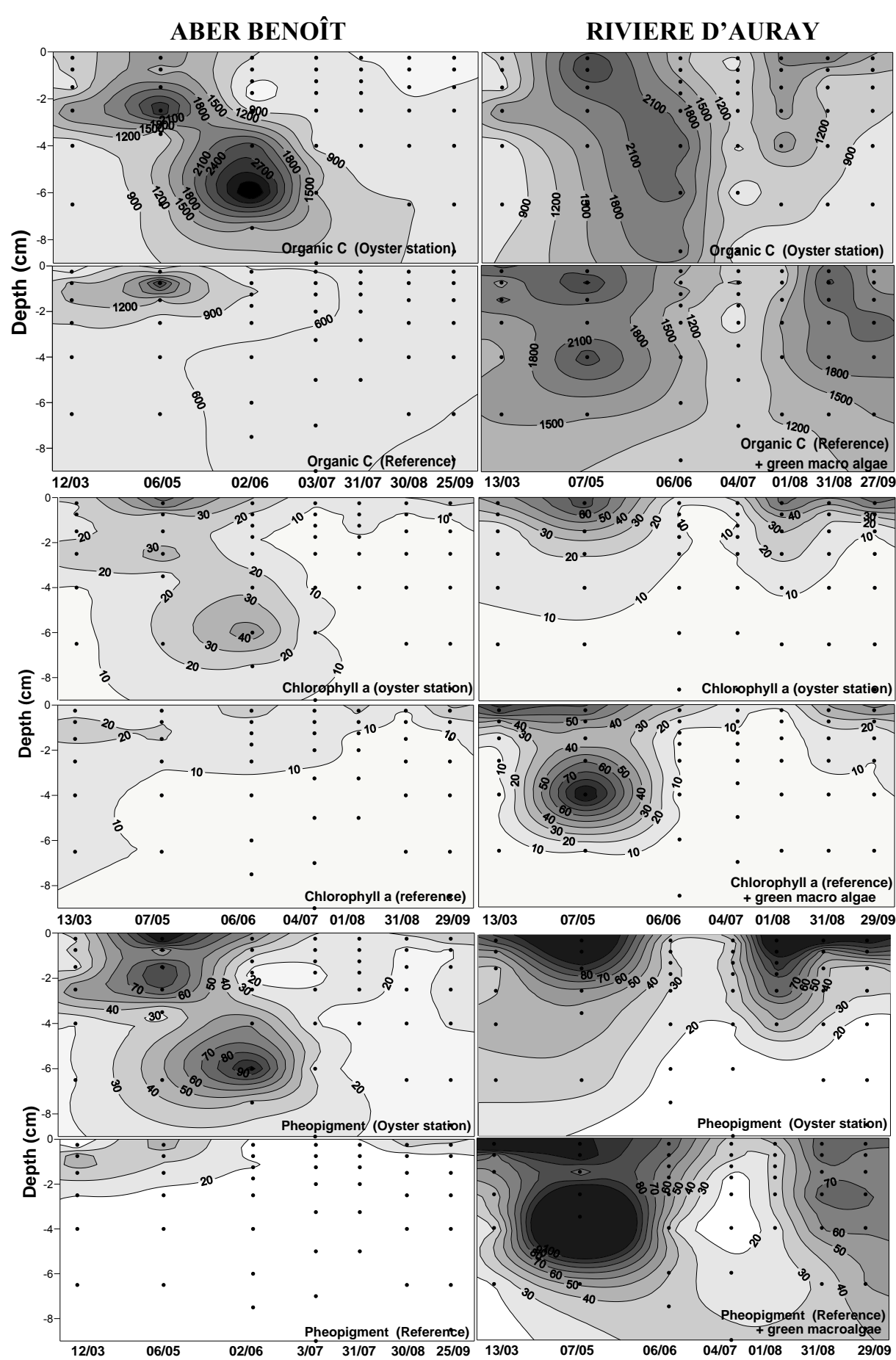
914

915

916
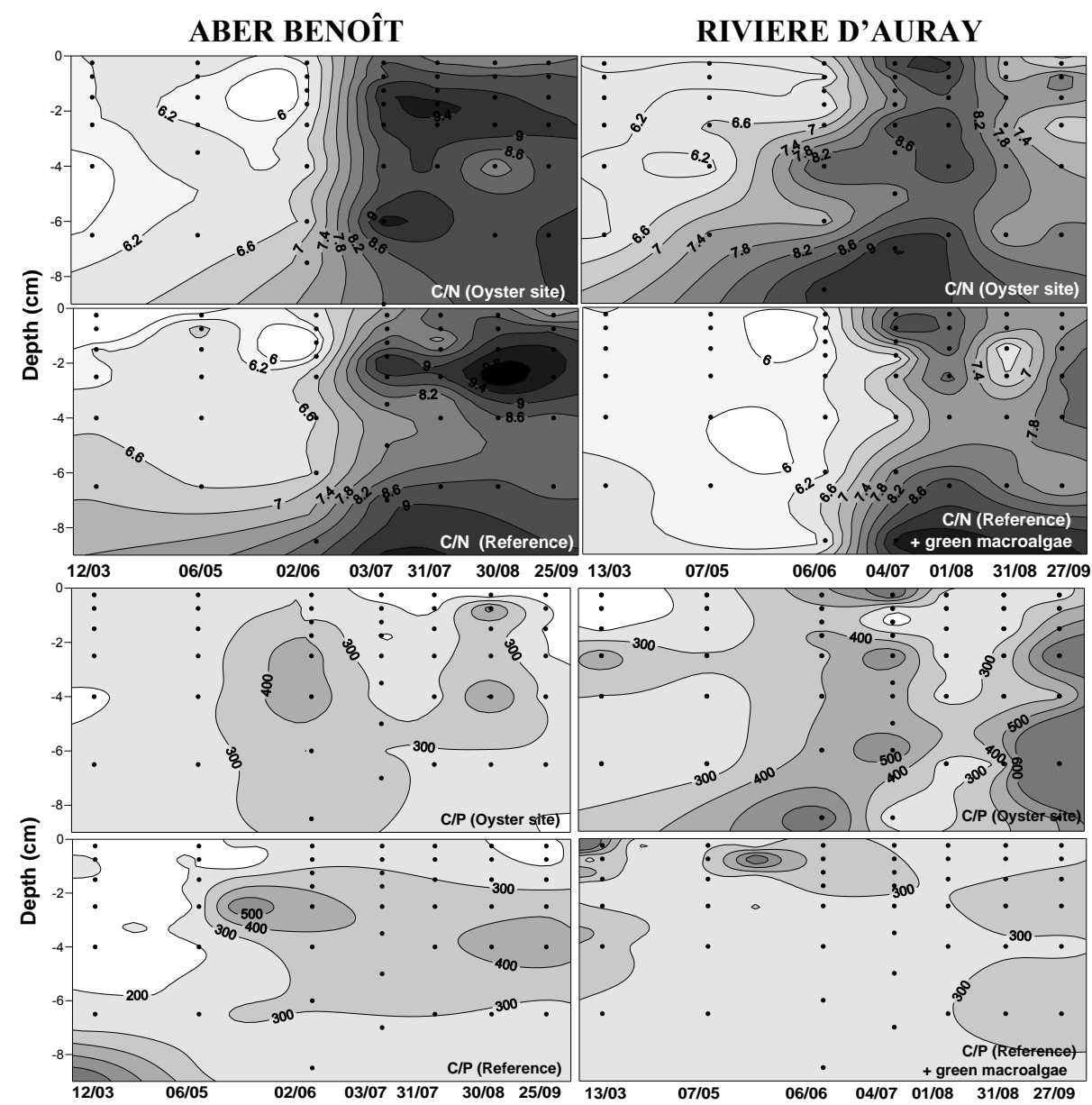

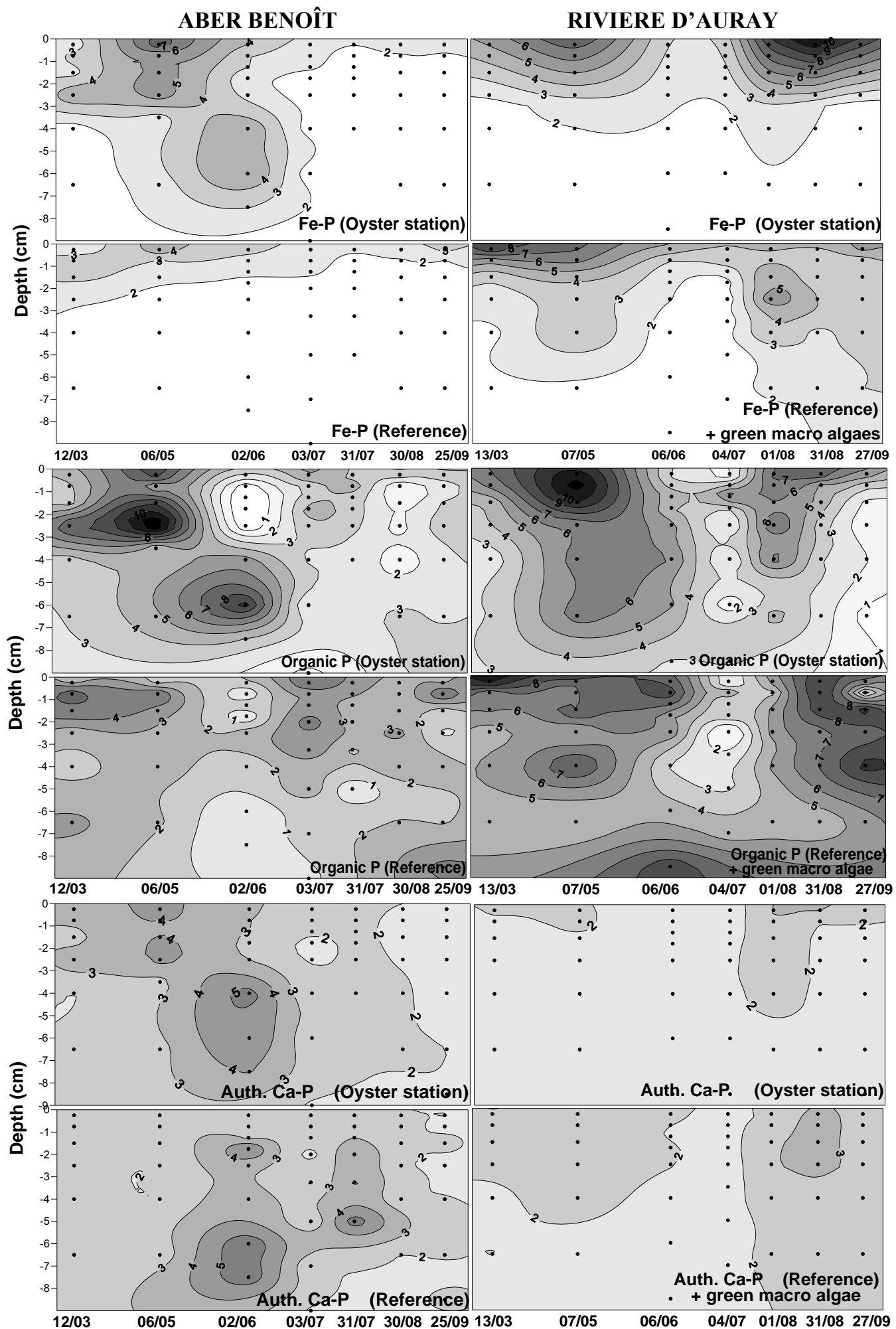

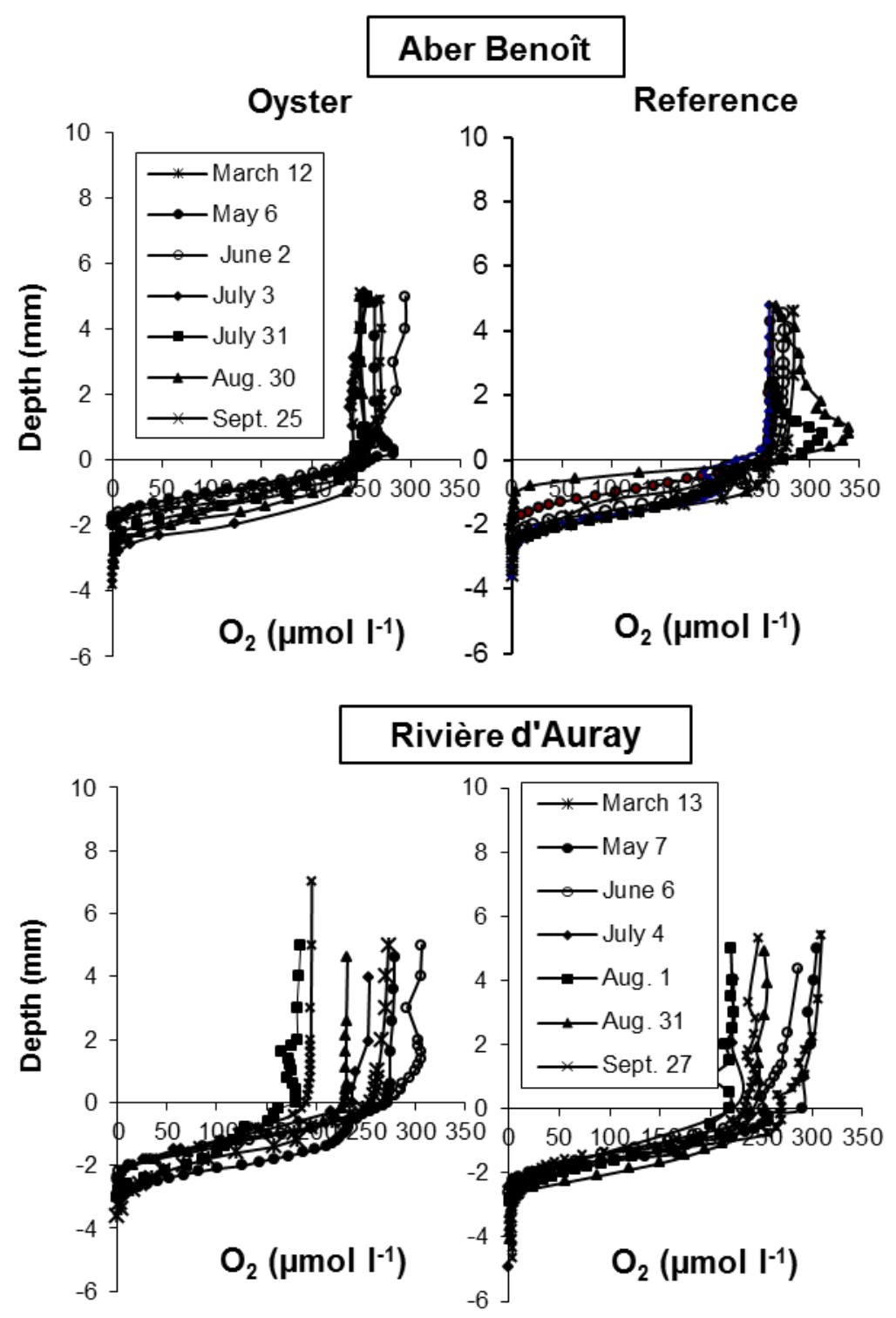

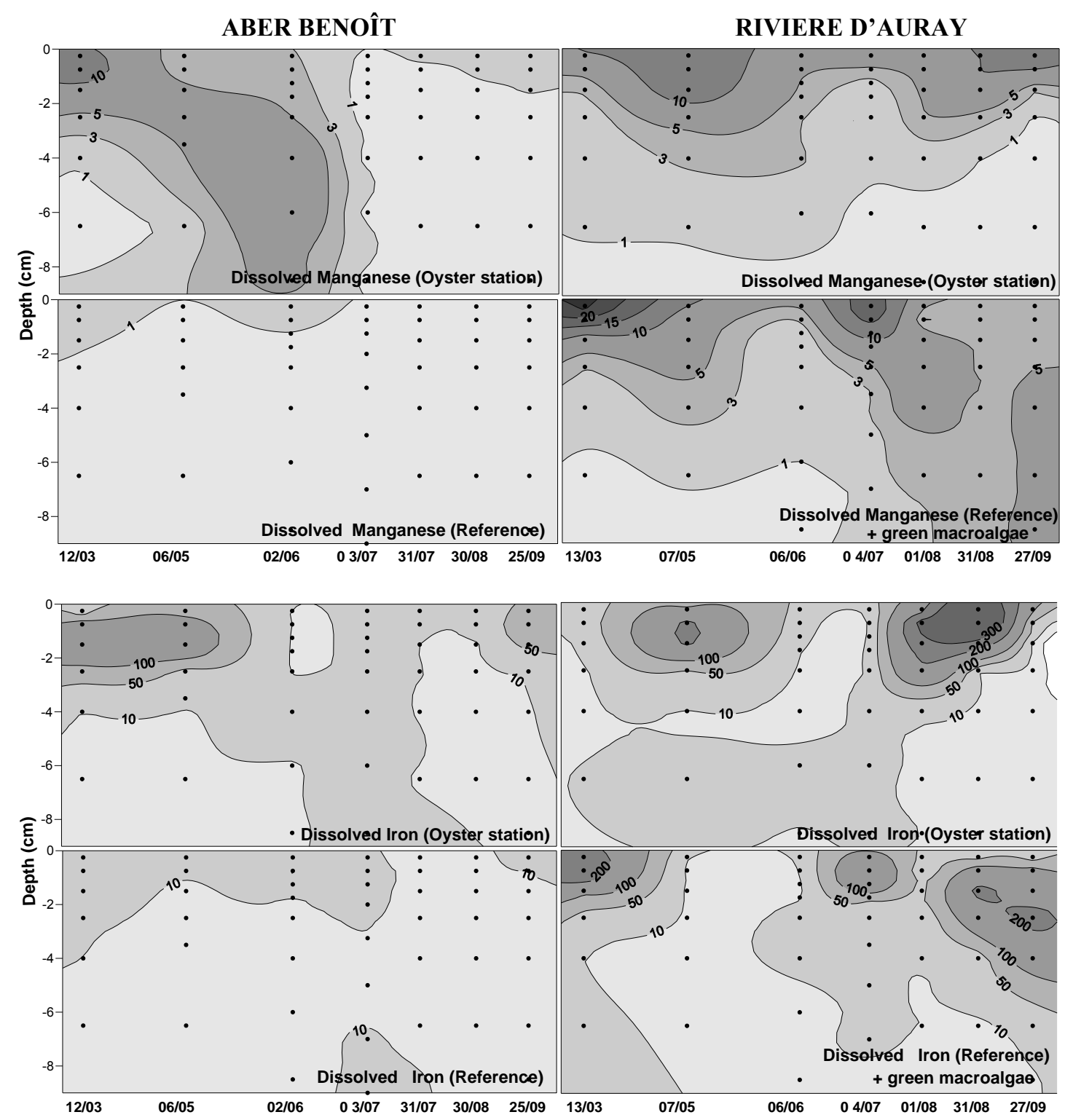

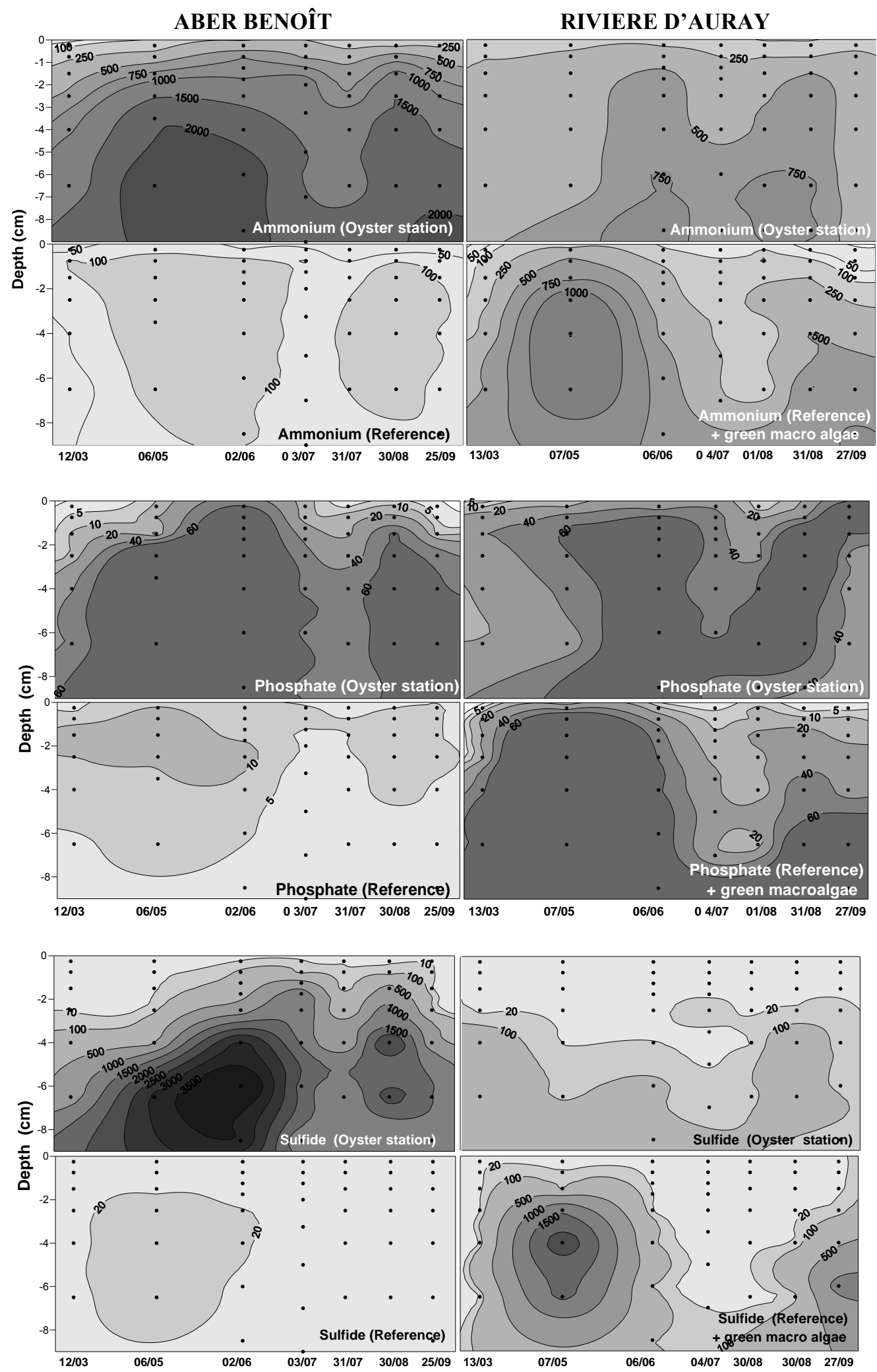
986

987
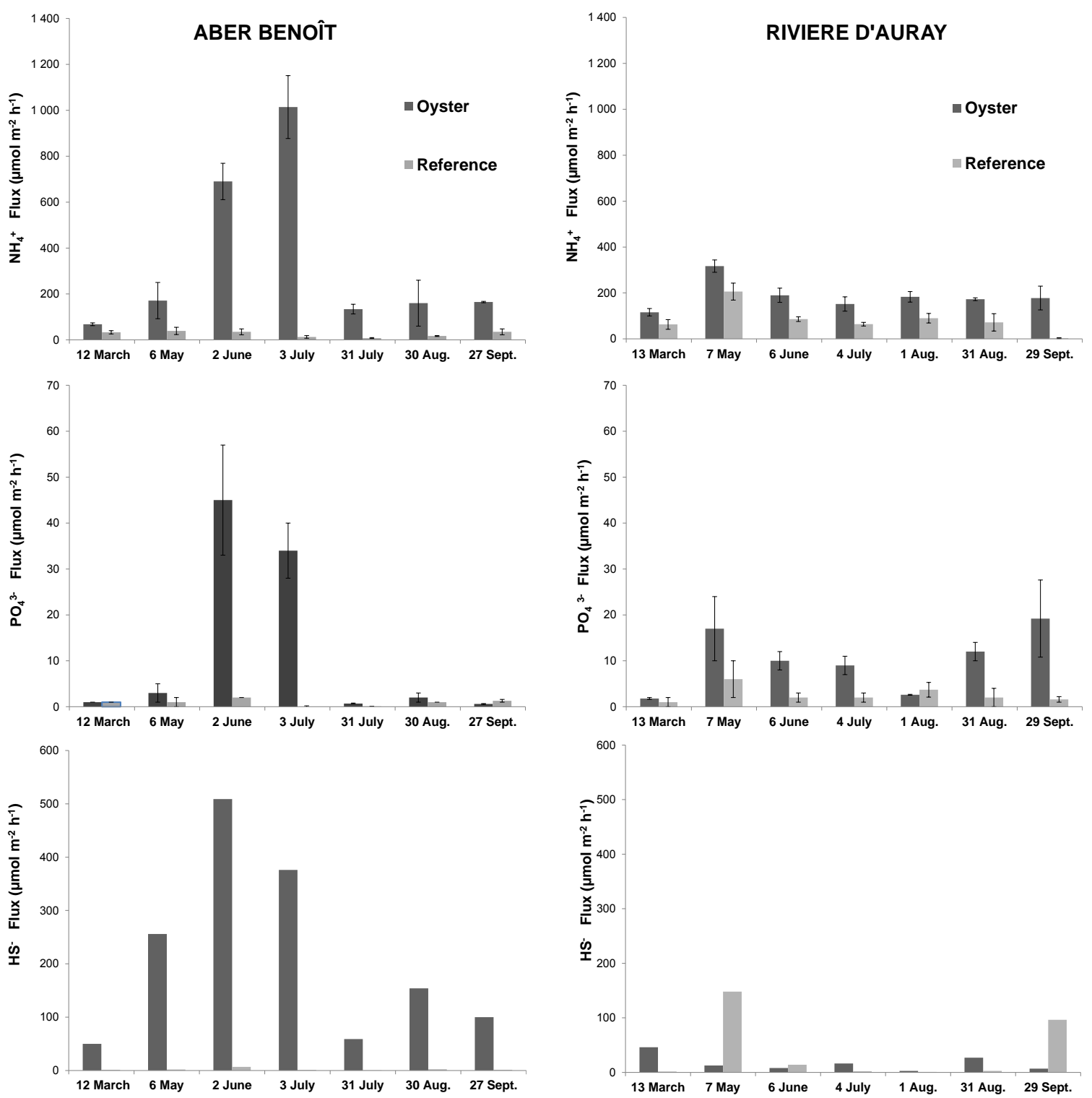
996
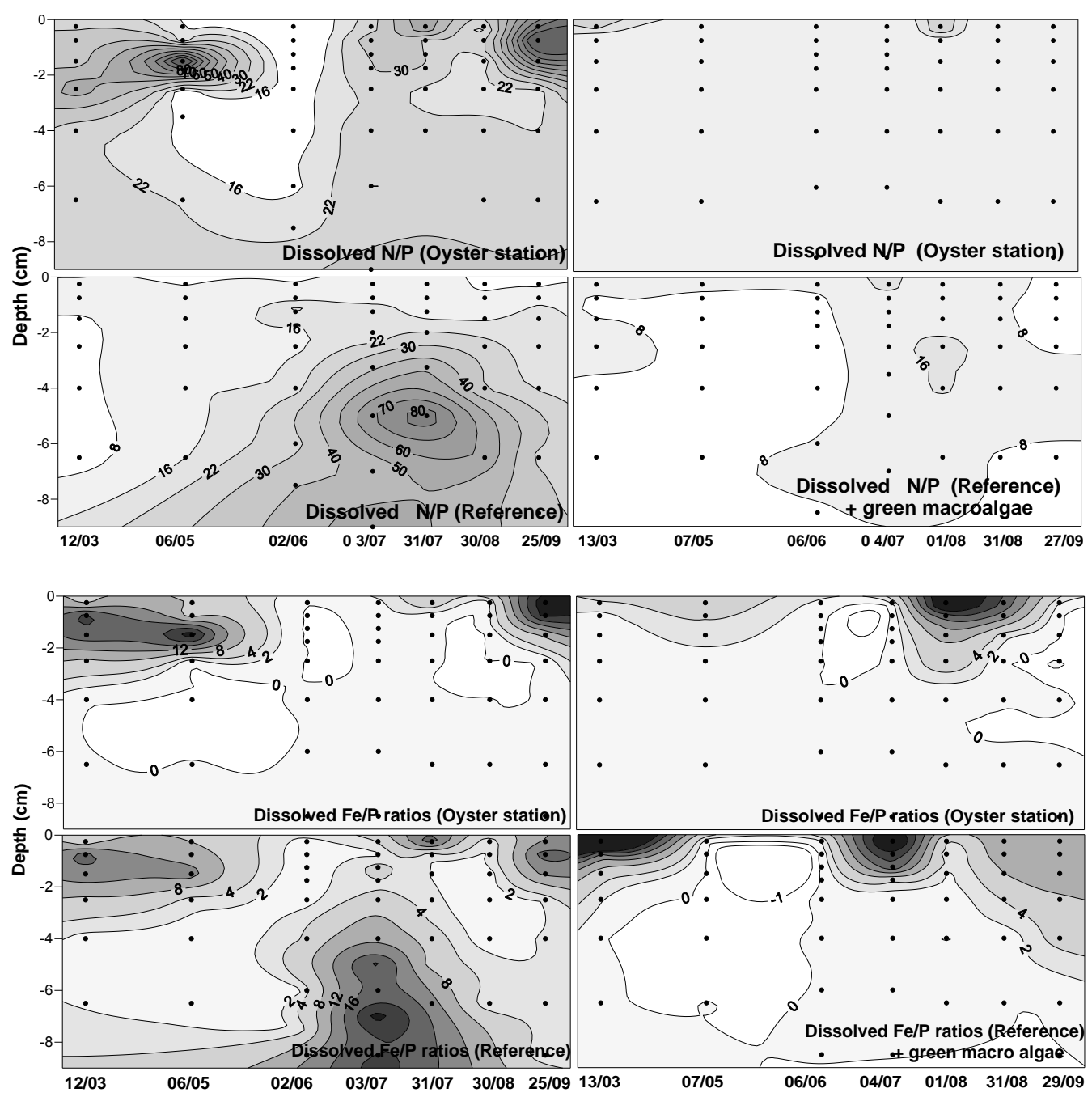

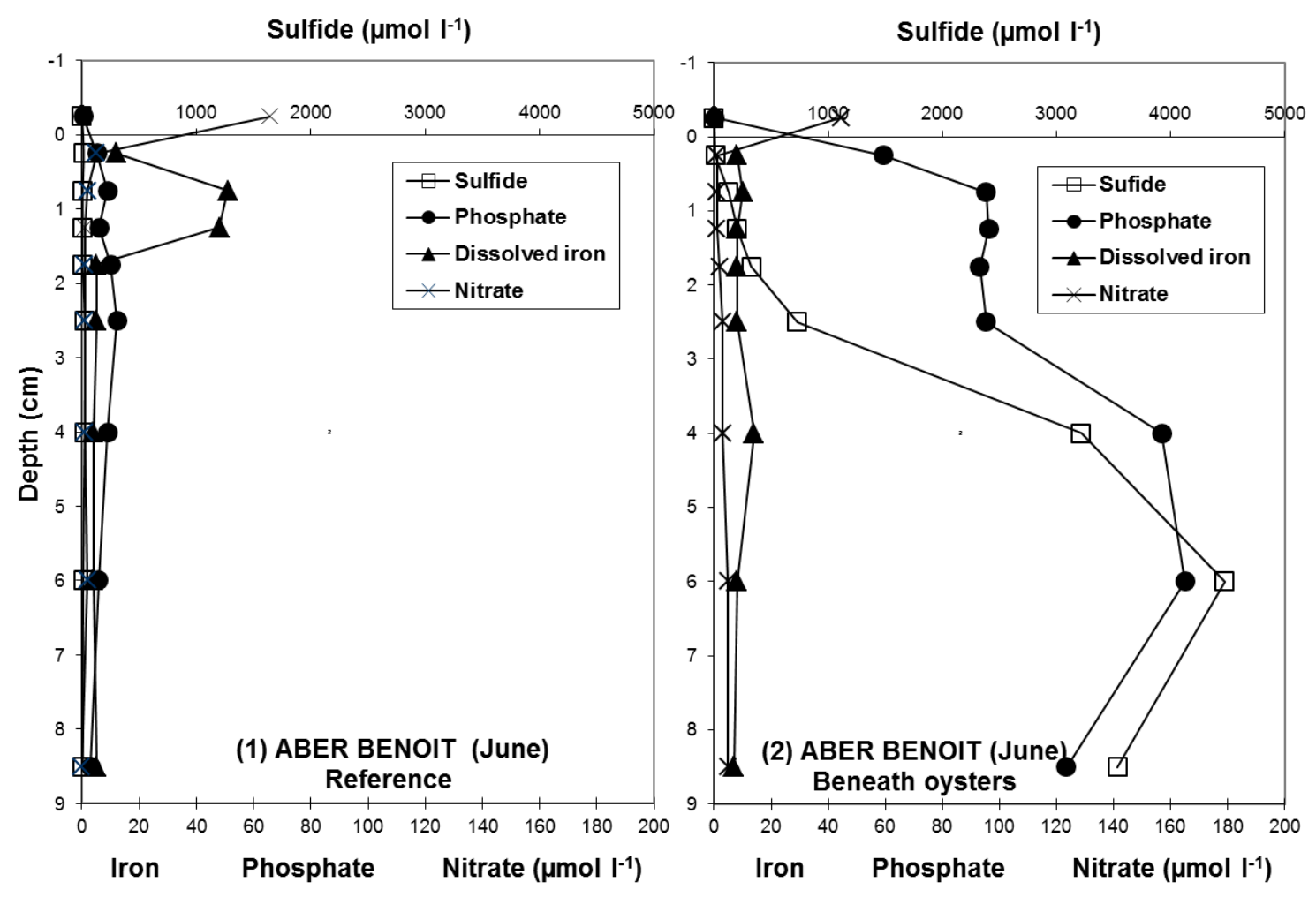

1015

1016

1017

1018

1019

1020

1021

1022

1023

1024 

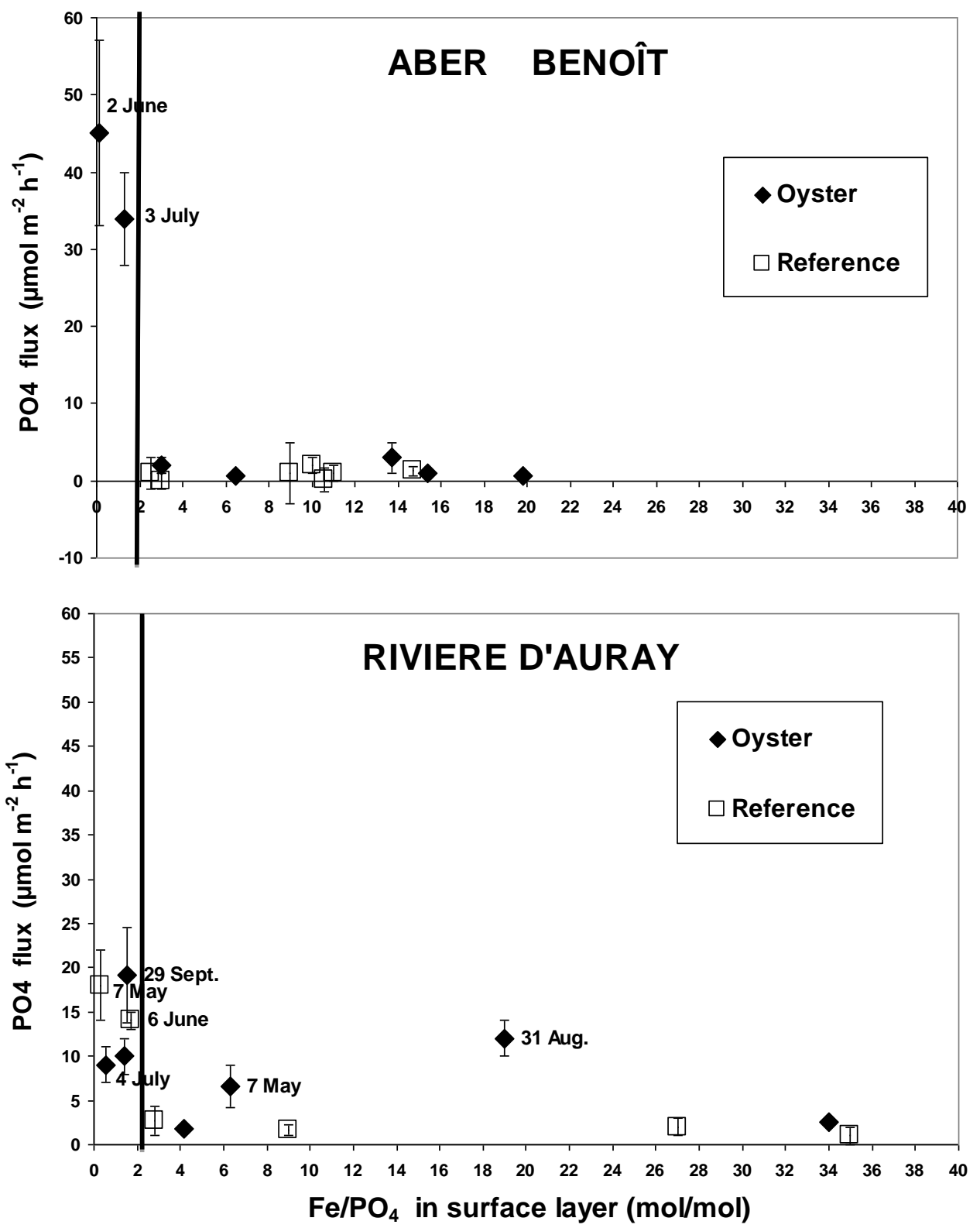

1028 $\mathrm{Fe} / \mathrm{PO}_{4}$ in surface layer $(\mathrm{mol} / \mathrm{mol})$ 
1036 Appendix

1037 See table 5

1038 Seasonal distributions (2007-2008) of particulate parameters (Phosphorus forms (adsorbed and iron-oxide bound

1039 P (Fe-P), Organic P (Orga-P), Authigenic Calcium bound P (Auth-Ca-P), Organic Carbon (Orga-C), Total

1040 Nitrogen (Total N), Chlorophyll a (Chl a), Phaeopigments) and dissolved parameters (Nitrate $\left(\mathrm{NO}_{3}\right)$,

1041 Ammonium $\left(\mathrm{NH}_{4}^{+}\right)$, phosphate $\left(\mathrm{HPO}_{4}{ }_{4}^{2-}\right.$ ) and sulfide $\left.\left(\mathrm{HS}^{-}\right)\right)$in sediments of the Aber Benoît and the Rivière

1042 d'Auray both under Oyster and at Reference sites. Phosphorus forms, Orga-C, Total N, are expressed in $\mu \mathrm{mol} \mathrm{g}^{-}$

$1043{ }^{1}$. Chl a, phaeopigments are expressed in $\mu \mathrm{g} \mathrm{g}^{-1}$ and dissolved parameters in $\mu \mathrm{mol} \mathrm{l}^{-1}$.

$1044 \mathrm{NH}_{4}{ }^{1}, \mathrm{PO}_{4}{ }^{1}$ : Concentrations in core 1

$1045 \mathrm{NH}_{4}^{2}, \mathrm{PO}_{4}^{2}$ : Mean concentrations for core 1,2 and 3.

1046

1047

1048

1049

1050

1051

1052

1053

1054

1055

1056

1057

1058

1059

1060

1061 
1063 Table 5

\begin{tabular}{|c|c|c|c|c|c|c|c|c|c|c|c|c|c|c|c|c|}
\hline \multicolumn{17}{|c|}{ ABER BENOÎT (OYSTER) } \\
\hline Date & Depth & $\mathrm{Fe}-\mathrm{P}$ & Auth-Ca-P & Orga-P & Orga-C & total $\mathrm{N}$ & Chlo a & Pheopigment & $\mathrm{NO}_{3}^{-}$ & $\mathrm{NH}_{4}{ }^{1}$ & $\mathrm{NH}_{4}{ }^{2}$ & $\mathrm{PO}_{4}{ }^{1}$ & $\mathrm{PO}_{4}{ }^{2}$ & $\mathrm{HS}^{-}$ & $\mathrm{Fe}^{2+}$ & $\mathrm{Mn}^{2+}$ \\
\hline & $\mathrm{cm}$ & \multicolumn{5}{|c|}{$\mu \mathrm{mol} \mathrm{g}^{-1}$} & \multicolumn{3}{|c|}{$\mu g^{-1}$} & \multicolumn{6}{|c|}{$\mu \mathrm{mol} \mathrm{I}^{-1}$} & \\
\hline \multirow[t]{6}{*}{$12 / 03$} & -0.25 & 2.3 & 3.6 & 4.4 & 963 & 184 & 19.0 & 27 & 2.0 & 79 & $67(10)$ & 2.8 & $2.2(1.0)$ & 7.1 & 25 & 11 \\
\hline & -0.75 & 3.3 & 3.2 & 3.9 & 1004 & 174 & 20.5 & 35 & 0.84 & 220 & 212(22) & 6.2 & $5.4(1.7)$ & 9.8 & 131 & 14 \\
\hline & -1.5 & 2.7 & 2.6 & 3.5 & 757 & 162 & 14.8 & 24 & 0.77 & 375 & - & 10.9 & - & 10.1 & 199 & 8 \\
\hline & -2.5 & 4.8 & 3.6 & 8.1 & 1846 & 312 & 29.6 & 60 & 0.91 & 547 & - & 9.8 & - & 7.7 & 70 & 4.4 \\
\hline & -4 & 1.5 & 2.0 & 3.4 & 656 & 119 & 8.5 & 20 & 2.93 & 926 & - & 37.2 & - & 250 & 10 & 1.1 \\
\hline & -6.5 & 1.4 & 2.1 & 3.1 & 664 & 110 & 7.0 & 19 & 2.93 & 1163 & - & 41.7 & - & 693 & 7 & 0.2 \\
\hline \multirow[t]{6}{*}{$06 / 05$} & -0.25 & 7.7 & 4.3 & 9.1 & 1872 & 288 & 66.5 & 122 & 7.9 & 174 & $170(27)$ & 10.2 & $9.1(3.2)$ & 10.4 & 81 & 2.9 \\
\hline & -0.75 & 5.0 & 4.0 & 4.8 & 1282 & 207 & 22.7 & 45 & 1.80 & 332 & $308(28)$ & 20.0 & $21.4(1.4)$ & 1.8 & 126 & 3.9 \\
\hline & -1.5 & 5.2 & 4.0 & 8.9 & 2019 & 329 & 18.5 & 92 & 0.84 & 802 & - & 6.6 & - & 2.1 & 178 & 5.5 \\
\hline & -2.5 & 5.5 & 4.3 & 12.5 & 3115 & 542 & 37.0 & 83 & 0.84 & 1463 & - & 132.6 & - & 53.3 & 30 & 6 \\
\hline & -3.5 & 2.6 & 2.6 & 3.9 & 893 & 138 & 16.0 & 25 & 2.72 & 1960 & - & 131.4 & - & 374 & 12 & 5.2 \\
\hline & -6.5 & 2.5 & 2.7 & 4.8 & 1045 & 163 & 20.9 & 47 & 2.92 & 2515 & - & 116.7 & - & 3145 & 10 & 1.3 \\
\hline \multirow[t]{8}{*}{$2 / 06$} & -0.25 & 4.0 & 3.2 & 3.0 & 914 & 158 & 28.0 & 57 & 1.00 & 741 & $768(34)$ & 61.9 & $135(63)$ & 9.5 & 8 & 3.2 \\
\hline & -0.75 & 3.1 & 3.0 & 1.1 & 731 & 123 & 18.3 & 35 & 0 & 789 & $913(132)$ & 95.9 & $148(45)$ & 128 & 10 & 3.5 \\
\hline & -1.25 & 3.0 & 3.0 & 1.1 & 629 & 109 & 15.2 & 27 & 0.29 & 894 & - & 96.3 & - & 203 & 8 & 3.8 \\
\hline & -1.75 & 2.2 & 2.6 & 1.3 & 428 & 71 & 10.2 & 14 & 0.85 & 981 & - & 93.2 & - & 327 & 8 & 4.4 \\
\hline & -2.5 & 2.7 & 2.9 & 1.2 & 823 & 129 & 14.4 & 26 & 0 & 1337 & - & 95.4 & - & 729 & 8 & 5 \\
\hline & -4 & 5.0 & 5.5 & 5.6 & 2613 & 415 & 28.8 & 59 & 0 & 1802 & - & 156.9 & - & 3214 & 34 & 9 \\
\hline & -6 & 5.3 & 5.0 & 9.4 & 3794 & 569 & 46.9 & 104 & 0 & 2365 & - & 165.0 & - & 4475 & 8 & 9 \\
\hline & -7.5 & 3.0 & 4.1 & 3.9 & 1462 & 205 & 18.8 & 37 & 0 & 2310 & - & 123.5 & - & 3537 & 7 & 6 \\
\hline \multirow[t]{8}{*}{$3 / 07$} & -0.25 & 2.5 & 2.3 & 5.3 & 743 & 85 & 10.7 & 26 & 0.50 & 496 & 1093(519) & 21.3 & $88(59)$ & 36.0 & 19 & 0.6 \\
\hline & -0.75 & 2.4 & 2.4 & 3.1 & 775 & 92 & 8.4 & 26 & 0.50 & 556 & $1186(547)$ & 23.5 & $69(65)$ & 41.4 & 16 & 0.6 \\
\hline & -1.25 & 2.2 & 2.3 & 3.4 & 860 & 91 & 8.8 & 21 & 0.50 & 779 & $1319(505)$ & 26.2 & $83(80)$ & 645 & 18 & 0.2 \\
\hline & -1.75 & 1.6 & 1.7 & 4.5 & 867 & 95 & 7.1 & 18 & 0.50 & 1126 & $1410(349)$ & 36.4 & $58(30)$ & 1358 & 18 & 0.2 \\
\hline & -2.5 & 1.6 & 1.9 & 3.8 & 856 & 94 & 7.6 & 21 & 0.40 & 1172 & $1453(294)$ & 48.0 & $57(13)$ & 1422 & 13 & 0.2 \\
\hline & -4 & 1.5 & 2.1 & 2.8 & 764 & 87 & 7.2 & 19 & 0.90 & 1399 & $1690(266)$ & 48.3 & $48(0.1)$ & 1417 & 17 & 0.2 \\
\hline & -6 & 1.3 & 2.1 & 1.7 & 1173 & 122 & 10.2 & 24 & 0.90 & 1449 & $1688(214)$ & 48.2 & $48(0.0)$ & 1791 & 20 & 0.2 \\
\hline & -9 & 1.2 & 1.9 & 1.7 & 1129 & 138 & 9.4 & 22 & 0.60 & 1577 & $1708(115)$ & 45.6 & $43(2.1)$ & 920 & 19 & 0.2 \\
\hline \multirow[t]{6}{*}{$31 / 07$} & -0.25 & 2.0 & 2.2 & 3.5 & 532 & 66 & 17.1 & 26 & 0.60 & 178 & $167(17)$ & 2.8 & $2.7(0.3)$ & 12.5 & 39 & 1.6 \\
\hline & -0.75 & 1.6 & 2.2 & 4.7 & 816 & 92 & 9.5 & 28 & 0.60 & 424 & $340(73)$ & 15.3 & $15.3(0.7)$ & 13.7 & 48 & 0.3 \\
\hline & -1.25 & 1.7 & 2.1 & 3.5 & 775 & 86 & 12.5 & 31 & 0.50 & 515 & - & 16.7 & - & 11.6 & 10 & 0.3 \\
\hline & -1.75 & 1.7 & 2.2 & 3.6 & 871 & 91 & 9.2 & 23 & 0.25 & 693 & - & 22.6 & - & 23.2 & 11 & 0.1 \\
\hline & -2.5 & 1.7 & 2.2 & 3.3 & 827 & 90 & 9.3 & 23 & 0.50 & 1016 & - & 50.7 & - & 323 & 9 & 0.1 \\
\hline & -4 & 1.7 & 2.4 & 2.9 & 738 & 82 & 7.6 & 19 & 0.25 & 1064 & - & 45.9 & - & 887 & 8 & 0.1 \\
\hline \multirow[t]{6}{*}{$30 / 08$} & -0.25 & 2.6 & 1.9 & 3.8 & 479 & 61 & 17.7 & 29 & 1.60 & 182 & $165(15)$ & 11.0 & $8.5(2.2)$ & 11.9 & 34 & 1.2 \\
\hline & -0.75 & 1.9 & 1.8 & 0.8 & 434 & 50 & 8.8 & 17 & 0.60 & 650 & $600(84)$ & 22.6 & $20.6(1.9)$ & 18.5 & 44 & 1.2 \\
\hline & -1.5 & 1.9 & 1.8 & 1.6 & 541 & 60 & 8.0 & 18 & 0.40 & 1082 & - & 65.4 & - & 649 & 14 & 0.8 \\
\hline & -2.5 & 1.8 & 1.9 & 1.7 & 632 & 68 & 7.5 & 18 & 0.60 & 1537 & - & 73.1 & - & 1370 & 5 & 0.3 \\
\hline & -4 & 1.8 & 2.1 & 1.4 & 715 & 91 & 7.2 & 17 & 0.90 & 2110 & - & 78.0 & - & 2792 & 6 & 0.1 \\
\hline & -6.5 & 1.8 & 2.1 & 3.4 & 921 & 107 & 6.4 & 17 & 0.90 & 2175 & - & 79.0 & - & 2342 & 6 & 0.2 \\
\hline \multirow[t]{7}{*}{$27 / 09$} & -0.25 & 2.6 & 2.0 & 3.8 & 582 & 72 & 23.0 & 38 & 2.95 & 209 & $218(10)$ & 2.4 & $2.4(0.3)$ & 11.6 & 49 & 1.6 \\
\hline & -0.75 & 1.8 & 1.8 & 2.3 & 510 & 58 & 10.5 & 19 & 0.85 & 451 & $514(67)$ & 3.6 & $3.8(0.3)$ & 23.5 & 99 & 1.1 \\
\hline & -1.5 & 1.7 & 1.8 & 3.1 & 611 & 70 & 8.5 & 22 & 0.35 & 628 & 682(191) & 7.4 & $7.8(0.3)$ & 17.9 & 61 & 1.1 \\
\hline & -2.5 & 1.8 & 1.9 & 3.8 & 790 & 87 & 7.9 & 22 & 0.45 & 961 & $913(87)$ & 51.2 & $45(5)$ & 34.8 & 13 & 0.4 \\
\hline & -4 & 1.7 & 1.8 & 2.7 & 753 & 85 & 6.6 & 21 & 0.95 & 1327 & - & 61.9 & - & 607 & 9 & 0.1 \\
\hline & -6.5 & 1.7 & 2.0 & 2.7 & 771 & 85 & 4.9 & 16 & 0.50 & 1786 & - & 73.2 & - & 1487 & 8 & 0.1 \\
\hline & -8.5 & 1.6 & 2.0 & 4.0 & 785.1 & 87 & 4.2 & 18 & 0.45 & 2124 & - & 71.6 & - & 1199 & 8 & 0.1 \\
\hline
\end{tabular}


1073 Table 5 (continued)

ABER BENOÎT (REFERENCE)

\begin{tabular}{|c|c|c|c|c|c|c|c|c|c|c|c|c|c|c|c|c|}
\hline \multicolumn{17}{|c|}{ ABER BENOÎT (REFERENCE) } \\
\hline Date & Depth & Fe-P & Auth-Ca-P & Orga-P & Orga-C & Total N & Chlo a & Phaeopigment & $\mathrm{NO}_{3}{ }^{-}$ & $\mathrm{NH}_{4}{ }^{1}$ & $\mathrm{NH}_{4}^{2}$ & $\mathrm{PO}_{4}{ }^{1}$ & $\mathrm{PO}_{4}^{2}$ & HS $^{-}$ & $\mathrm{Fe}^{2+}$ & $\mathrm{Mn}^{2+}$ \\
\hline & $\mathrm{cm}$ & & & $\mu \mathrm{mol} \mathrm{g}{ }^{-1}$ & & & & $\mu \mathrm{g} \mathrm{g}^{-1}$ & & & & $\mu \mathrm{mol} \mathrm{I} \mathrm{I}^{-1}$ & & & & \\
\hline \multirow[t]{6}{*}{$12 / 03$} & -0.25 & 1.7 & 2.0 & 2.4 & 433 & 81 & 8.2 & 9.1 & 5.0 & 32.6 & $40.5(7.3)$ & 3.8 & $3.13(0.99)$ & 11.3 & 25 & 2.2 \\
\hline & -0.75 & 4.4 & 2.4 & 7.4 & 1317 & 242 & 28.0 & 50.5 & 2.0 & 106.3 & $100(6.8)$ & 7.4 & $12.4(4.33)$ & 9.2 & 36 & 1.7 \\
\hline & -1.5 & 3.2 & 2.5 & 4.9 & 1238 & 199 & 21.6 & 35.6 & 0.9 & 93.7 & & 14.0 & & 6.8 & 32 & 1.2 \\
\hline & -2.5 & 2.2 & 2.2 & 2.4 & 900 & 148 & 13.3 & 19.5 & 0.9 & 65.3 & & 9.8 & & 10.1 & 14 & 0.8 \\
\hline & -4 & 1.7 & 2.3 & 1.5 & 722 & 110 & 11.4 & 14.3 & 0.9 & 49.7 & & 7.9 & & 6.3 & 10 & 0.3 \\
\hline & -6.5 & 1.6 & 2.4 & 3.3 & 828 & 119 & 10.5 & 16.9 & 22 & 17.4 & & 3.8 & & 9.5 & 3 & 0.3 \\
\hline \multirow[t]{6}{*}{ 06/05 } & -0.25 & 4.6 & 2.9 & 1.6 & 800 & 135 & 11.2 & 47.2 & 5.0 & 73.0 & $52.7(22.2)$ & 10.1 & $5.63(3.89)$ & 10.1 & 24 & 0.8 \\
\hline & -0.75 & 2.9 & 2.7 & 5.3 & 2856 & 419 & 20.0 & 31.5 & 1.0 & 147.9 & $134(14)$ & 12.9 & $10.4(2.36)$ & 5.4 & 14 & 0.6 \\
\hline & -1.5 & 2.3 & 2.3 & 3.5 & 1157 & 181 & 20.7 & 27.2 & 0.9 & 147.9 & & 12.9 & & 9.5 & 4.0 & 0.3 \\
\hline & -2.5 & 1.5 & 2.0 & 2.8 & 751 & 115 & 10.6 & 15.2 & 0.9 & 135.7 & & 10.1 & & 55.7 & 1.0 & 0.1 \\
\hline & -4 & 1.3 & 2.0 & 2.7 & 651 & 102 & 8.8 & 12.1 & 0.9 & 155.0 & & 9.7 & & 67.3 & 2.0 & 0.1 \\
\hline & -6.5 & 1.4 & 2.3 & 2.2 & 862 & 131 & 9.9 & 14.4 & 1.0 & 126.0 & & 8.0 & & 50.9 & 2.0 & 0.1 \\
\hline \multirow[t]{8}{*}{$02 / 06$} & -0.25 & 3.3 & 2.3 & 1.8 & 584 & 92 & 25.1 & 16.9 & 4.0 & 41.0 & $50.3(13)$ & 5.3 & $6.13(0.72)$ & 13.7 & 12 & 2.1 \\
\hline & -0.75 & 2.6 & 2.5 & 0.0 & 848 & 140 & 16.6 & 17.8 & 2.0 & 118.4 & 103(13) & 8.9 & $9.53(0.55)$ & 5.1 & 51 & 1.3 \\
\hline & -1.25 & 2.3 & 2.7 & 1.9 & 971 & 173 & 14.1 & 22.3 & 0.9 & 153.7 & & 6.0 & & 5.1 & 48 & 1.0 \\
\hline & -1.75 & 1.6 & 5.3 & 0.0 & 672 & 113 & 10.0 & 13.5 & 1.0 & 156.3 & & 10.1 & & 5.1 & 5.0 & 0.5 \\
\hline & -2.5 & 1.7 & 3.3 & 2.5 & 850 & 126 & 12.8 & 19.7 & 0.9 & 176.4 & & 12.3 & & 22.9 & 5.0 & 0.4 \\
\hline & -4 & 1.0 & 3.6 & 1.1 & 404 & 62 & 6.2 & 7.2 & 0.9 & 165.4 & & 9.0 & & 22.6 & 4.0 & 0.3 \\
\hline & -6 & 1.1 & 5.8 & 0.0 & 367 & 56 & 6.3 & 6.8 & 2.0 & 160.2 & & 5.9 & & 9.5 & 4.0 & 0.2 \\
\hline & -7.5 & 1.0 & 5.7 & 0.0 & 428 & 58 & 5.4 & 6.6 & 0.0 & 118.9 & & 3.0 & & 5.1 & 5.0 & 0.1 \\
\hline \multirow[t]{8}{*}{ 03/07 } & -0.25 & 2.5 & 2.3 & 5.3 & 582 & 78 & 13.0 & 17.3 & 2.0 & 33.0 & $23.3(8.5)$ & 3.0 & $2.29(0.62)$ & 13.4 & 13 & 0.7 \\
\hline & -0.75 & 2.4 & 2.4 & 3.1 & 759 & 94 & 10.3 & 13.8 & 0.7 & 104.4 & $83(20)$ & 10.9 & $9.54(1.18)$ & 14.9 & 26 & 0.4 \\
\hline & -1.25 & 2.2 & 2.3 & 3.4 & 712 & 86 & 10.7 & 13.8 & 0.7 & 83.2 & $87(7.4)$ & 3.5 & $5.23(1.45)$ & 10.1 & 13 & 0.2 \\
\hline & -2 & 1.6 & 1.7 & 4.5 & 788 & 82 & 16.6 & 19.4 & 1.0 & 74.3 & $74(3.3)$ & 4.7 & $4.88(0.37)$ & 12.5 & 14 & 0.2 \\
\hline & -3.25 & 1.6 & 1.9 & 3.8 & 424 & 52 & 6.5 & 10.2 & 1.0 & 54.9 & $54(3)$ & 1.4 & $1.93(0.53)$ & 11.3 & 10 & 0.2 \\
\hline & -5 & 1.5 & 2.1 & 2.8 & 483 & 62 & 8.5 & 10.6 & 1.0 & 56.6 & $55(11.4)$ & 0.8 & $0.91(0.16)$ & 10.4 & 10 & 0.2 \\
\hline & -7 & 1.3 & 2.1 & 1.7 & 476 & 53 & 5.0 & 9.0 & 1.0 & 31.9 & $33.1(5.3)$ & 0.8 & $0.84(0.1)$ & 6.8 & 12 & 0.1 \\
\hline & -9 & 1.2 & 1.9 & 0.7 & 478 & 50 & 7.9 & 18.7 & 1.0 & 49.6 & $46.8(2.6)$ & 0.9 & $0.78(0.12)$ & 9.8 & 13 & 0.2 \\
\hline \multirow[t]{6}{*}{$31 / 07$} & -0.25 & 2.1 & 2.1 & 3.7 & 486 & 57 & 22.8 & 16.6 & 5.0 & 13.4 & $15.7(2.1)$ & 1.0 & $1.12(0.17)$ & 14.3 & 7.0 & 0.2 \\
\hline & -0.75 & 1.7 & 2.7 & 3.2 & 485 & 59 & 12.6 & 13.5 & 1.0 & 48.2 & $36.8(9.9)$ & 5.2 & $4.65(0.91)$ & 12.8 & 9.0 & 0.3 \\
\hline & -1.25 & 1.7 & 3.0 & 2.5 & 468 & 62 & 9.4 & 11.6 & 0.9 & 62.9 & & 4.8 & & 11.6 & 6.0 & 0.3 \\
\hline & -2 & 1.4 & 4.0 & 2.6 & 462 & 51 & 7.0 & 9.1 & 1.0 & 100.7 & & 4.6 & & 11.3 & 4.0 & 0.2 \\
\hline & -3.25 & 1.2 & 4.1 & 1.8 & 394 & 50 & 5.7 & 6.6 & 0.9 & 120.3 & & 2.5 & & 10.1 & 3.0 & 0.2 \\
\hline & -5 & 1.0 & 5.6 & 0.0 & 385 & 49 & 4.8 & 6.6 & 1.0 & 103.8 & & 1.2 & & 8.0 & 4.0 & 0.1 \\
\hline \multirow[t]{6}{*}{$30 / 08$} & -0.25 & 2.6 & 2.1 & 2.6 & 494 & 57 & 8.2 & 34.9 & 3.0 & 28.1 & $25.5(3.6)$ & 4.2 & $3.68(0.51)$ & 11.3 & 9.0 & 0.2 \\
\hline & -0.75 & 1.9 & 2.1 & 2.4 & 505 & 57 & 9.5 & 13.6 & 1.0 & 95.9 & $89.1(5.9)$ & 10.4 & $8.94(1.32)$ & 12.8 & 10.0 & 0.2 \\
\hline & -1.5 & 1.7 & 2.0 & 2.5 & 480 & 51 & 8.2 & 11.1 & 1.0 & 170.3 & & 11.2 & & 19.9 & 4.0 & 0.2 \\
\hline & -2.5 & 1.7 & 2.1 & 3.3 & 496 & 48 & 11.0 & 14.3 & 1.0 & 164.8 & & 6.7 & & 14.6 & 4.0 & 0.2 \\
\hline & -4 & 1.8 & 2.1 & 3.0 & 555 & 65 & 9.2 & 12.7 & 0.9 & 235.1 & & 8.2 & & 19.0 & 5.0 & 0.2 \\
\hline & -6.5 & 1.5 & 2.0 & 2.1 & 437 & 50 & 6.9 & 8.2 & 1.0 & 180.7 & & 3.1 & & 10.1 & 9.0 & 0.1 \\
\hline \multirow[t]{7}{*}{$27 / 09$} & -0.25 & 3.2 & 2.0 & 2.8 & 612 & 81 & 32.5 & 30.5 & 3.8 & 32.9 & $44.6(15.3)$ & 5.5 & $4.72(0.74)$ & 16.4 & 24 & 0.4 \\
\hline & -0.75 & 2.0 & 1.9 & 5.2 & 491 & 55 & 13.3 & 16.6 & 0.9 & 76.2 & 89.2(20.6) & 5.1 & $5.36(1.62)$ & 13.4 & 10 & 0.3 \\
\hline & -1.5 & 1.7 & 2.1 & 1.4 & 478 & 51 & 9.1 & 11.1 & 0.9 & 90.9 & $89.4(1.4)$ & 4.9 & $4.79(0.65)$ & 12.5 & 7.0 & 0.2 \\
\hline & -2.5 & 1.4 & 1.9 & 0.8 & 500 & 53 & 8.2 & 9.8 & 0.9 & 109.8 & $95.3(12.9)$ & 6.1 & $6.12(0.19)$ & 18.2 & 4.0 & 0.2 \\
\hline & -4 & 1.4 & 2.0 & 2.3 & 522 & 62 & 8.3 & 11.7 & 0.8 & 83.2 & & 4.0 & & 17.0 & 4.0 & 0.1 \\
\hline & -6.5 & 1.4 & 2.1 & 1.9 & 612 & 73 & 8.0 & 13.6 & 1.7 & 56.7 & & 2.1 & & 17.9 & 5.0 & 0.1 \\
\hline & -8.5 & 1.5 & 2.1 & 4.3 & 865 & 96 & 9.6 & 16.7 & 2.0 & 97.0 & & 3.0 & & 13.4 & 5.0 & 0.1 \\
\hline
\end{tabular}

1075 
1081 Table 5 (continued)

RIVIERE D'AURAY (OYSTER)

\begin{tabular}{|c|c|c|c|c|c|c|c|c|c|c|c|c|c|c|c|c|}
\hline \multirow{3}{*}{$\begin{array}{l}\text { Date } \\
13 / 03\end{array}$} & \multirow{2}{*}{$\frac{\text { Depth }}{\mathrm{cm}}$} & \multicolumn{2}{|c|}{ Fe-P Auth-Ca-P } & \multirow{2}{*}{\multicolumn{2}{|c|}{$\frac{\text { Orga-P Orga-C }}{\mu \mathrm{mol} \mathrm{g}}$}} & \multirow[t]{2}{*}{ Total $\mathbf{N}$} & \multicolumn{2}{|c|}{ Chl a Phaeopigment } & \multirow[t]{2}{*}{$\mathrm{NO}_{3}^{-}$} & \multirow[t]{2}{*}{$\mathrm{NH}_{4}{ }^{1}$} & \multirow[t]{2}{*}{$\mathrm{NH}_{4}{ }^{2}$} & $\mathrm{PO}_{4}{ }^{1}$ & $\mathrm{PO}_{4}{ }^{2}$ & \multirow[t]{2}{*}{ HS" $^{-}$} & \multirow[t]{2}{*}{$\mathrm{Fe}^{2+}$} & \multirow[t]{2}{*}{$\mathrm{Mn}^{2+}$} \\
\hline & & & & & & & & $g^{-1}$ & & & & \multicolumn{2}{|c|}{$\mu \mathrm{mol} \mathrm{I}^{-1}$} & & & \\
\hline & -0.25 & 5.1 & 2.1 & 6.9 & 2467 & 468 & 83 & 86 & 2.0 & 125 & $109(25)$ & 5.3 & $5(0.7)$ & 3.9 & 22.0 & 10.0 \\
\hline & -0.75 & 4.1 & 1.9 & 6.4 & 1617 & 310 & 35 & 58 & 1.0 & 243 & $242(48)$ & 33.2 & $35.8(2.9)$ & 6.8 & 33.0 & 6.0 \\
\hline & -1.5 & 2.2 & 1.5 & 4.2 & 2189 & 436 & 13 & 37 & 1.0 & 286 & & 39.5 & & 8.0 & 16.0 & 3.3 \\
\hline & -2.5 & 1.6 & 1.4 & 4.0 & 1558 & 300 & 7 & 39 & 0.1 & 303 & & 25.3 & & 2.4 & 6.0 & 1.5 \\
\hline & -4 & 1.5 & 1.4 & 2.3 & 1454 & 273 & 4 & 45 & 0.1 & 297 & & 22.1 & & 227.1 & 8.0 & 1.3 \\
\hline & -6.5 & 1.4 & 1.6 & 3.0 & 1545 & 286 & 2 & 34 & 0.0 & 266 & & 20.8 & & 167.3 & 12.0 & 1.2 \\
\hline \multirow[t]{6}{*}{ 07/05 } & -0.25 & 8.0 & 2.1 & 10.4 & 2238 & 435 & 70 & 144 & 2.0 & 193 & $185(30)$ & 14.4 & $27(25.8)$ & 9.5 & 91.0 & 13.0 \\
\hline & -0.75 & 7.4 & 2.2 & 11.5 & 2777 & 518 & 47 & 121 & 2.0 & 316 & $322(31)$ & 52.5 & $70(40.2)$ & 7.7 & 221.0 & 14.0 \\
\hline & -1.5 & 5.9 & 1.9 & 10.0 & 2174 & 411 & 31 & 96 & 1.0 & 393 & & 63.8 & & 7.1 & 212.0 & 14.0 \\
\hline & -2.5 & 2.8 & 1.5 & 6.2 & 1750 & 311 & 60 & 57 & 0.1 & 415 & & 57.6 & & 8.0 & 42.0 & 6.2 \\
\hline & -4 & 1.9 & 1.9 & 6.5 & 2599 & 523 & 106 & 47 & 2.0 & 410 & & 45.2 & & 11.6 & 9.0 & 3.5 \\
\hline & -6.5 & 1.2 & 1.2 & 6.5 & 1534 & 249 & 9 & 37 & 0.0 & 309 & & 23.4 & & 87.8 & 20.0 & 1.2 \\
\hline $6 / 06$ & -0.25 & 2.5 & 1.0 & 2.7 & 1603 & 295 & 28 & 24 & 2.0 & 222 & $214(11)$ & 29.3 & $28.8(1.1)$ & 7.1 & 41.0 & 6.5 \\
\hline & -0.75 & 3.1 & 1.6 & 3.6 & 1339 & 244 & 15 & 25 & 3.0 & 397 & $407(22)$ & 66.0 & $57.1(17.1)$ & 2.1 & 30.0 & 5.5 \\
\hline & -1.25 & 2.4 & 1.3 & 4.8 & 1788 & 302 & 9 & 31 & 2.0 & 491 & & 88.1 & & 3.9 & 27.0 & 4.8 \\
\hline & -1.75 & 2.9 & 1.6 & 3.9 & 1246 & 211 & 8 & 32 & 2.0 & 576 & & 93.4 & & 5.1 & 12.0 & 4.6 \\
\hline & -2.5 & 2.3 & 1.5 & 5.4 & 1324 & 230 & 8 & 27 & 0.1 & 565 & & 81.6 & & 12.8 & 7.0 & 3.1 \\
\hline & -4 & 2.0 & 1.7 & 6.0 & 1526 & 251 & 4 & 23 & 0.0 & 578 & & 73.8 & & 20.8 & 4.0 & 3.3 \\
\hline & -6 & 1.4 & 1.0 & 5.2 & 1371 & 233 & 4 & 15 & 0.0 & 805 & & 105.3 & & 141.4 & 14.0 & 2.0 \\
\hline & -8.5 & 1.1 & 0.8 & 2.9 & 971 & 166 & 4 & 10 & 0.0 & 1002 & & 119.7 & & 205.1 & 9.0 & 0.7 \\
\hline $4 / 07$ & -0.25 & 2.3 & 1.3 & 1.1 & 986 & 109 & 12 & 35 & 1.0 & 173 & $145(25)$ & 27.4 & $23.3(3.7)$ & 6.0 & 15.0 & 8.5 \\
\hline & -0.75 & 1.8 & 1.6 & 4.0 & 1262 & 152 & 11 & 39 & 1.0 & 247 & $240(7)$ & 48.7 & $41.2(6.9)$ & 1.5 & 14.0 & 4.3 \\
\hline & -1.25 & 1.9 & 1.5 & 6.7 & 947 & 116 & 9 & 43 & 1.0 & 310 & $314(24)$ & 46.3 & $40.7(8.0)$ & 9.8 & 12.0 & 2.4 \\
\hline & -1.75 & 2.1 & 1.7 & 3.0 & 870 & 111 & 5 & 36 & 1.0 & 351 & $346(24)$ & 51.1 & $49.2(3.7)$ & 13.4 & 19.0 & 1.6 \\
\hline & -2.5 & 1.9 & 1.8 & 1.7 & 801 & 90 & 6 & 33 & 1.0 & 395 & $376(19)$ & 51.4 & $49.1(2.2)$ & 48.8 & 14.0 & 0.6 \\
\hline & -4 & 1.5 & 1.5 & 1.7 & 938 & 114 & 4 & 18 & 1.0 & 413 & $392(25)$ & 41.9 & $45.5(5.1)$ & 13.7 & 17.0 & 0.8 \\
\hline & -6 & 1.2 & 1.1 & 1.1 & 936 & 117 & 5 & 10 & 1.0 & 469 & $462(37)$ & 43.6 & $48.0(6.3)$ & 9.5 & 19.0 & 0.4 \\
\hline & -8.5 & 1.1 & 1.2 & 3.1 & 1124 & 119 & 2 & 9 & 1.0 & 434 & $475(36)$ & 37.7 & $36.4(2.2)$ & 9.8 & 12.0 & 0.5 \\
\hline $1 / 08$ & -0.25 & 8.6 & 3.1 & 7.5 & 1023 & 112 & 7 & 137 & 2.0 & 117 & $125(25)$ & 4.4 & $5.2(1.2)$ & 7.7 & 149.0 & 6.5 \\
\hline & -0.75 & 4.9 & 2.8 & 6.4 & 1067 & 120 & 6 & 110 & 1.0 & 248 & $230(49)$ & 19.2 & 18.9(3.1) & 7.7 & 349.0 & 6.0 \\
\hline & -1.5 & 4.0 & 2.8 & 6.0 & 1372 & 160 & 6 & 93 & 1.0 & 343 & & 25.4 & & 9.2 & 258.0 & 5.5 \\
\hline & -2.5 & 3.3 & 2.6 & 7.1 & 1562 & 176 & 7 & 83 & 1.0 & 438 & & 27.8 & & 7.1 & 197.0 & 5.0 \\
\hline & -4 & 3.0 & 3.0 & 6.7 & 1484 & 163 & 5 & 51 & 1.5 & 535 & & 60.5 & & 9.5 & 18.0 & 2.5 \\
\hline & -6.5 & 2.2 & 1.9 & 4.5 & 1250 & 139 & 2 & 21 & 0.0 & 888 & & 122.9 & & 24.7 & 4.0 & 0.9 \\
\hline $31 / 08$ & -0.25 & 11.1 & 3.2 & 8.0 & 2363 & 330 & 39 & 114 & 2.0 & 118 & $114(5)$ & 23.1 & $20.0(2.8)$ & 8.0 & 451.0 & 10.0 \\
\hline & -0.75 & 4.5 & 2.0 & 4.8 & 2445 & 338 & 24 & 59 & 1.0 & 238 & 218(19) & 38.4 & $34.7(4.7)$ & 14.3 & 540.0 & 10.0 \\
\hline & -1.5 & 3.5 & 1.8 & 4.7 & 2239 & 286 & 15 & 41 & 1.0 & 503 & & 105.2 & & 14.3 & 256.0 & 10.0 \\
\hline & -2.5 & 2.4 & 1.7 & 3.4 & 1897 & 255 & 13 & 38 & 1.0 & 749 & & 144.2 & & 25.3 & 10.0 & 4.0 \\
\hline & -4 & 1.8 & 1.6 & 3.0 & 2064 & 257 & 8 & 26 & 1.0 & 744 & & 93.4 & & 293.2 & 5.0 & 1.0 \\
\hline & -6.5 & 1.3 & 1.3 & 2.6 & 1234 & 168 & 4 & 12 & 0.0 & 831 & & 72.4 & & 457.4 & 7.0 & 0.2 \\
\hline $29 / 09$ & -0.25 & 8.1 & 2.4 & 5.7 & 1671 & 257 & 52 & 106 & 1.0 & 161 & $137(42)$ & 65.0 & $39.7(22.1)$ & 6.0 & 108.0 & 14.0 \\
\hline & -0.75 & 4.4 & 2.2 & 3.4 & 1725 & 212 & 22 & 83 & 1.0 & 342 & $343(47)$ & 118.4 & $101.3(15.9$ & 7.7 & 46.0 & 10.0 \\
\hline & -1.5 & 2.0 & 1.4 & 1.8 & 1875 & 246 & 13 & 31 & 1.0 & 342 & & 58.8 & & 14.9 & 6.0 & 3.1 \\
\hline & -2.5 & 1.6 & 1.5 & 1.3 & 2271 & 336 & 10 & 32 & 1.0 & 282 & & 28.7 & & 33.9 & 5.0 & 0.8 \\
\hline & -4 & 1.1 & 1.3 & 2.1 & 1938 & 263 & 9 & 14 & 1.0 & 270 & & 25.9 & & 40.5 & 5.0 & 0.4 \\
\hline & -6.5 & 1.1 & 1.2 & 0.5 & 1515 & 190 & 5 & 10 & 1.0 & 274 & & 25.5 & & 14.6 & 4.0 & 0.3 \\
\hline & -8.5 & 0.9 & 1.7 & 1.2 & 1320 & 161 & 4 & 8 & 1.5 & 284 & & 25.9 & & 6.0 & 9.0 & 0.2 \\
\hline
\end{tabular}

1083

1084 
1088 Table 5 (continued)

\begin{tabular}{|c|c|c|c|c|c|c|c|c|c|c|c|c|c|c|c|c|}
\hline \multicolumn{17}{|c|}{ RIVIERE D'AURAY (REFERENCE) } \\
\hline Date & \multirow{2}{*}{$\begin{array}{c}\text { Depth } \\
\mathrm{cm}\end{array}$} & \multirow[t]{2}{*}{ Fe-P } & \multirow{2}{*}{ Auth-Ca-P } & \multirow{2}{*}{$\begin{array}{r}\text { Orga-P } \\
\mu_{\mathrm{mol} \mathrm{g}}{ }^{-1}\end{array}$} & \multirow{2}{*}{ Orga-C } & \multirow[t]{2}{*}{ Total $\mathbf{N}$} & \multicolumn{2}{|c|}{ Chl a Phaeopigment } & \multirow[t]{2}{*}{$\mathrm{NO}_{3}^{-}$} & \multirow[t]{2}{*}{$\mathrm{NH}_{4}{ }^{1}$} & \multirow[t]{2}{*}{$\mathrm{NH}_{4}{ }^{2}$} & \multirow{2}{*}{\multicolumn{2}{|c|}{$\frac{\mathbf{P O}_{4}{ }^{\mathbf{1}} \mathbf{P O}_{4}{ }^{\mathbf{2}}}{\left.\mu \mathrm{mol} \mathrm{I}\right|^{-1}}$}} & \multirow[t]{2}{*}{ HS $^{-}$} & \multirow[t]{2}{*}{$\mathrm{Fe}^{2+}$} & \multirow[t]{2}{*}{$\mathrm{Mn}^{2+}$} \\
\hline & & & & & & & & & & & & & & & & \\
\hline $13 / 03$ & -0.25 & 8.8 & 3.0 & 10.9 & 959 & 165 & 42 & 144 & 11.0 & 55.1 & $47.7(14.5)$ & 4.3 & 3.3(1.1) & 5.4 & 234.0 & 27.0 \\
\hline & -0.75 & 5.5 & 2.3 & 6.0 & 917 & 163 & 30 & 66 & 2.80 & 141.5 & 144(32) & 21.0 & $20.5(2.9)$ & 8.3 & 320.0 & 19.0 \\
\hline & -1.5 & 3.3 & 2.5 & 6.2 & 740 & 160 & 8 & 61 & 0.80 & 156.9 & & 19.4 & & 5.1 & 112.0 & 7.0 \\
\hline & -2.5 & 2.3 & 2.2 & 4.5 & 1824 & 334 & 16 & 45 & 0.85 & 192.7 & & 14.4 & & 6.0 & 32.0 & 3.1 \\
\hline & -4 & 1.8 & 1.7 & 5.1 & 682 & 128 & 13 & 28 & 0.92 & 292.3 & & 52.8 & & 11.6 & 10.0 & 1.3 \\
\hline & -6.5 & 1.8 & 2.0 & 4.2 & 658 & 104 & 3 & 20 & 0.85 & 505.2 & & 66.2 & & 6.3 & 19.0 & 0.5 \\
\hline $07 / 05$ & -0.25 & 7.1 & 2.7 & 8.2 & 2529 & 490 & 77 & 99 & 2.80 & 145.0 & $114(30)$ & 12.0 & $8.3(4.7)$ & 5.4 & 11.0 & 10.0 \\
\hline & -0.75 & 6.3 & 2.7 & 4.2 & 2690 & 487 & 62 & 113 & 0.80 & 591.4 & $493(95)$ & 115.5 & $94(24)$ & 25.9 & 7.0 & 7.0 \\
\hline & -1.5 & 4.4 & 2.8 & 8.4 & 2269 & 434 & 39 & 73 & 0.78 & 679.0 & & 154.0 & & 78.9 & 7.0 & 7.0 \\
\hline & -2.5 & 3.3 & 2.7 & 4.8 & 1918 & 334 & 21 & 126 & 0.70 & 1289.1 & & 216.9 & & 1439.3 & 8.0 & 6.0 \\
\hline & -4 & 4.3 & 2.5 & 8.4 & 1636 & 305 & 17 & 212 & 0.70 & 1546.0 & & 218.5 & & 2415.2 & 7.0 & 4.3 \\
\hline & -6.5 & 1.8 & 1.7 & 3.6 & 1496 & 276 & 7 & 51 & 0.50 & 1338.0 & & 170.5 & & 1639.9 & 6.0 & 1.4 \\
\hline $6 / 06$ & -0.25 & 4.7 & 2.2 & 7.6 & 1271 & 223 & 11 & 74 & 11.7 & 102.4 & $117(13.5)$ & 10.0 & $6.1(3.5)$ & 5.1 & 17.0 & 5.2 \\
\hline & -0.75 & 3.1 & 2.0 & 8.5 & 1362 & 240 & 9 & 68 & 14.8 & 213.1 & $236(45)$ & 31.5 & $20.4(9.6)$ & 3.0 & 12.0 & 3.4 \\
\hline & -1.25 & 2.4 & 1.9 & 7.3 & 1564 & 290 & 11 & 60 & 2.92 & 291.0 & & 45.0 & & 6.0 & 5.0 & 1.7 \\
\hline & -1.75 & 2.3 & 2.2 & 5.1 & 1746 & 329 & 12 & 56 & 0.92 & 309.9 & & 49.9 & & 23.2 & 6.0 & 1.3 \\
\hline & -2.5 & 2.1 & 2.1 & 5.9 & 2021 & 373 & 10 & 50 & 0.00 & 337.9 & & 56.3 & & 5.4 & 33.0 & 1.4 \\
\hline & -4 & 1.4 & 1.5 & 2.9 & 2364 & 433 & 8 & 26 & 0 & 427.1 & & 62.6 & & 128.0 & 15.0 & 1.3 \\
\hline & -6 & 1.5 & 1.4 & 4.6 & 2211 & 395 & 5 & 37 & 0 & 619.2 & & 76.2 & & 93.5 & 5.0 & 1.0 \\
\hline & -8.5 & 1.5 & 1.7 & 8.9 & 1996 & 365 & 3 & 36 & 0 & 673.8 & & 93.6 & & 101.5 & 7.0 & 0.5 \\
\hline $4 / 07$ & -0.25 & 3.8 & 1.7 & 1.2 & 831 & 98 & 16 & 29 & 1.0 & 68.4 & $59.8(8.7)$ & 3.6 & $4.6(1.4)$ & 1.8 & 101.0 & 19.0 \\
\hline & -0.75 & 3.6 & 2.0 & 5.2 & 901 & 102 & 14 & 35 & 1.0 & 110.6 & $100(9.1)$ & 8.8 & $8.3(1.1)$ & 1.5 & 200.0 & 16.0 \\
\hline & -1.25 & 2.4 & 1.7 & 1.9 & 1022 & 131 & 8 & 24 & 1.0 & 140.9 & $143(10)$ & 9.2 & 12(2) & 5.4 & 176.0 & 12.0 \\
\hline & -1.75 & 1.7 & 1.7 & 4.0 & 1018 & 164 & 14 & 15 & 1.0 & 170.6 & 178(7) & 13.2 & 14(2) & 3.9 & 61.0 & 8.0 \\
\hline & -2.5 & 1.5 & 1.6 & 0.0 & 1026 & 141 & 10 & 16 & 1.0 & 191.4 & & 16.1 & & 5.1 & 14.0 & 4.6 \\
\hline & -3.5 & 1.4 & 1.6 & 2.2 & 776 & 120 & 5 & 13 & 1.0 & 242.0 & & 23.5 & & 6.8 & 16.0 & 2.8 \\
\hline & -5 & 1.3 & 1.6 & 2.8 & 651 & 82 & 3 & 19 & 0.9 & 258.0 & & 28.6 & & 8.3 & 14.0 & 2.3 \\
\hline & -7 & 1.3 & 1.9 & 4.3 & 690 & 72 & 3 & 24 & 1.0 & 293.1 & & 23.1 & & 20.2 & 14.0 & 1.3 \\
\hline $1 / 08$ & -0.25 & 4.1 & 2.2 & 5.5 & 1903 & 226 & 66 & 41 & 1.9 & 93.9 & $81(13)$ & 9.1 & $8.2(1.1)$ & 9.2 & 36.0 & 5.3 \\
\hline & -0.75 & 3.9 & 2.3 & 3.7 & 1700 & 200 & 43 & 32 & 0.9 & 115.3 & 103(13) & 13.3 & 11(2.4) & 9.8 & 20.0 & 2.9 \\
\hline & -1.5 & 5.2 & 2.8 & 5.2 & 1671 & 196 & 31 & 35 & 0.8 & 221.2 & & 25.0 & & 9.5 & 43.0 & 7.0 \\
\hline & -2.5 & 5.7 & 2.9 & 5.6 & 1573 & 186 & 25 & 35 & 0.9 & 325.8 & & 15.5 & & 9.5 & 13.0 & 9.5 \\
\hline & -4 & 4.1 & 2.6 & 5.3 & 1690 & 215 & 13 & 25 & 3.0 & 105.2 & & 5.9 & & 9.5 & 13.0 & 8.0 \\
\hline & -6.5 & 2.4 & 2.2 & 4.8 & 1175 & 132 & 6 & 22 & 3.0 & 79.7 & & 8.2 & & 9.5 & 10.0 & 5.0 \\
\hline $31 / 08$ & -0.25 & 3.9 & 3.2 & 9.0 & 2095 & 281 & 42 & 77 & 1.9 & 39.2 & $49(21)$ & 2.6 & $3.4(2.4)$ & 3.9 & 23.0 & 3.9 \\
\hline & -0.75 & 3.2 & 3.4 & 8.9 & 1289 & 169 & 22 & 78 & 1.0 & 113.6 & $127(42)$ & 11.7 & $15.8(8.5)$ & 9.2 & 134.0 & 3.4 \\
\hline & -1.5 & 3.0 & 3.3 & 8.6 & 984 & 165 & 17 & 66 & 0.9 & 250.7 & & 27.9 & & 7.7 & 224.0 & 4.6 \\
\hline & -2.5 & 4.0 & 3.0 & 6.5 & 1182 & 185 & 12 & 78 & 1.1 & 359.4 & & 36.5 & & 8.3 & 153.0 & 4.4 \\
\hline & -4 & 2.7 & 2.9 & 7.0 & 1055 & 142 & 7 & 62 & 1.5 & 529.8 & & 62.5 & & 14.9 & 25.0 & 3.7 \\
\hline & -6.5 & 1.9 & 2.2 & 4.2 & 830 & 104 & 3 & 33 & 0.0 & 793.8 & & 105.3 & & 30.7 & 5.0 & 1.7 \\
\hline $29 / 09$ & -0.25 & 5.2 & 2.6 & 7.3 & 1443 & 192 & 65 & 76 & 1.8 & 4.3 & $4.5(2.2)$ & 2.9 & $3.6(0.6)$ & 5.1 & 26.0 & 3.8 \\
\hline & -0.75 & 3.5 & 2.5 & 2.3 & 1289 & 168 & 33 & 62 & 0.9 & 28.7 & $30.4(3.8)$ & 12.3 & $12.4(1.6)$ & 5.4 & 121.0 & 3.6 \\
\hline & -1.5 & 3.1 & 2.5 & 9.5 & 903 & 113 & 11 & 62 & 0.8 & 68.9 & & 11.7 & & 5.4 & 137.0 & 3.5 \\
\hline & -2.5 & 3.4 & 2.9 & 7.4 & 969 & 116 & 7 & 70 & 0.8 & 218.0 & & 32.4 & & 46.4 & 232.0 & 5.0 \\
\hline & -4 & 3.6 & 2.6 & 9.4 & 775 & 94 & 3 & 62 & 1.2 & 414.0 & & 27.2 & & 457.4 & 146.0 & 6.1 \\
\hline & -6.5 & 3.0 & 2.5 & 5.5 & 728 & 99 & 2 & 52 & 1.2 & 598.0 & & 95.6 & & 1219.0 & 21.0 & 6.6 \\
\hline
\end{tabular}

